\title{
A gendered assessment of the brain drain
}

F. Docquier, B. Lindsay Lowell and A. Marfouk

Discussion Paper 2007-45

Département des Sciences Économiques

de l'Université catholique de Louvain 


\title{
A gendered assessment of the brain drain
}

\author{
Frédéric Docquier $^{a}$, B. Lindsay Lowell ${ }^{b}$ and Abdeslam Marfouk ${ }^{c}$ \\ ${ }^{a}$ National Fund for Scientific Research, IRES, Cath. Univ. of Louvain and World Bank \\ ${ }^{b}$ ISIM, Georgetown University $\quad{ }^{c}$ Universite Libre de Bruxelles
}

November 2007

\begin{abstract}
This paper updates and extends the Docquier-Marfouk data set on international migration by educational attainment. We use new sources, homogenize definitions of what a migrant is, and compute gender-disaggregated indicators of the brain drain. Emigration stocks and rates are provided by level of schooling and gender for 195 source countries in 1990 and 2000. Our data set can be used to capture the recent trend in women's brain drain and to analyze its causes and consequences for developing countries. We show that women represent an increasing share of the OECD immigration stock and exhibit relatively higher rates of brain drain than men. The gender gap in skilled migration is strongly correlated with the gender gap in educational attainment at origin. Equating women's and men's access to education would probably reduce gender differences in the brain drain.
\end{abstract}

JEL Classification: F22, J61.

Keywords: Brain drain, Gender, Human capital, Migration.

This paper is a product of the World Bank research program on the international migration of women initiated in December 2005. It benefitted from the financial support of the World Bank (Contract PO. 7620076). We thank Caglar Ozden and Maurice Schiff for their support and suggestions, as well as Daniel Reyes and Mirja Sjoblom for their help. Corresponding author: Frédéric Docquier, IRES, Catholic University of Louvain, Place Montesquieu, B-1348 Louvain-La-Neuve, Belgium. E-mail: <frederic.docquier@uclouvain.be>. 


\section{Contents}

1 Introduction . . . . . . . . . . . . . . . . . . 3

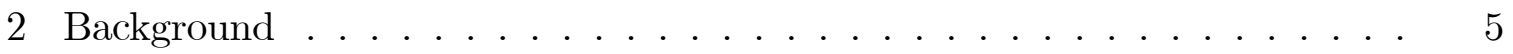

3 Emigration stocks by education level and gender . . . . . . . . . . . . 7

3.1 Methodology and data sources . . . . . . . . . . . . . . 7

3.2 Women's share in OECD immigration . . . . . . . . . . . . . . . . . . . . . 12

3.3 Stocks by education level and gender . . . . . . . . . . . . . . 14

4 Emigration rates . . . . . . . . . . . . . . . . . . . . . . . 19

4.1 Methodology and data sources . . . . . . . . . . . . . . . . . 19

4.2 Emigration rates by education level and gender . . . . . . . . . 23

5 Conclusion . . . . . . . . . . . . . . . . . . . 30 


\section{Introduction}

International migration is a diverse phenomenon and its impact on source and destination countries has attracted the increased attention of policymakers, scientists and international agencies. The migration pressure has increased over the last years and is expected to intensify in the coming decades given the rising gap in wages and the differing demographic futures in developed and developing countries. Understanding and measuring the consequences for migrants, host countries' residents and those left behind is a major and difficult task. In particular, the impact of the brain drain on sending countries results from a complex combination of direct and feedback effects which are extremely difficult to quantify.

Due to the lack of harmonized data, the brain drain debate has, until recently, remained essentially theoretical ${ }^{1}$. New data sets have been developed to assess the magnitude of the brain drain. In particular, Docquier and Marfouk $(2006)^{2}$ provided estimates of emigration stocks and rates by educational attainment for 195 source countries in 2000 and 174 countries in 1990. This data set gave rise to a couple of extensions as well as to a number of empirical studies on the determinants and consequences of the brain drain ${ }^{3}$.

One important extension which has been strongly disregarded in the literature concerns the gender gap in international migration. In particular, a little research has adressed the issue of female migration while a considerable strand of literature focused attention on male migration. The share of women in international migration increased over the last decades. According to the United Nations, this share increased from 46.8 to 49.6 percent between 1960 and 2005. This evolution is mostly due to the rising representation of women in the immigration stock of the most advanced countries (from 48.9 to 52.2 percent) ${ }^{4}$. It results from many factors such as the rise in women's educational attainment, the increased demand for women's labor in health care sectors and other services, or cultural and social changes in the attitude towards female migration in many source countries. Although family reunion programs admit many women in destination countries, women cannot be considered as passive companion migrants. The feminization of international migration raises specific economic issues related to the gendered determinants and consequences of migration. In particular, women's bain drain is likely to affect sending countries in a very peculiar way.

First of all, women's level of schooling is a fundamental ingredient for growth. Many studies demonstrated that women's education complements children's investments in school and has important effects on the human capital of future generations. Better educated mothers are superior teachers in the home, as demonstrated

\footnotetext{
${ }^{1}$ See Commander et al. (2004) or Docquier and Rapoport (2007) for literature surveys.

${ }^{2}$ Henceforth, DM06.

${ }^{3}$ See Docquier et al. (2007), Beine et al. (2007b), Cecchi et al. (2007), Krueger and Rapoport (2006), Nimi and Ozden (2006), Beata et al. (2006), Grogger and Hanson (2007), Easterly and Nyarko (2005), etc.

${ }^{4}$ In developing countries, the share of women has been relatively stable over time.
} 
by Behrman et al. (1997) in the case of India. Hence, for a given investment in children, more educated mothers produce children with higher levels of human capital (Haveman and Wolfe 1995, Summers 1992). It can also be argued that schooled women contribute more income to the household, which may lead to more investment in child schooling and lower fertility rates. Another argument is that mothers with high level of education have greater command of resources within the household (higher bargaining power), which they choose to allocate to children at higher levels than would men. Unsurprisingly, at the aggregate level, many studies have emphasized the role of female education in raising labor productivity and economic growth, suggesting that educational gender gaps are an impediment to economic development. This is the result obtained in Knowles et al. (2000) who use Barro and Lee's human capital indicators, or Coulombe and Tremblay (2006) who relied on the International Adult Literacy Survey to build an homogenized indicator of human capital. These studies suggest that investment in the human capital of women is crucial in countries where the gender gap in education is high ${ }^{5}$. Societies that have a preference for not investing in girls or that loose a high proportion of skilled women through emigration may experience slower growth and reduced income.

Second, women's brain drain is a crucial issue as women's human capital is an even scarcer resource than men's human capital. At the world level, the percentage of women with post-secondary education rose from 7.3 to 9.8 percent between 1990 and 2000, while the male proportion rose from 10.9 to 12.5 percent. Similarly, the percentage of women with completed secondary education rose from 31.6 to 34.7 percent during the same period while the male proportion rose from 45.4 to 46.8 percent. Although the gender gap decreases over time, women are still lagging far behind men. In addition, the convergence movement is mainly perceptible in highincome countries where recent generations of women are as well or more educated than young men. In low-income countries, the gender gap is much greater (in 2000, only 2.4 percent of women had post-secondary education, against 5.5 percent for men) and the convergence is slow. As women still face a unequal access to tertiary education in less developed countries, women's brain drain may generate higher relative losses than male brain drain.

Finally, as documented in Morrison, Schiff and Sjoblom (2007), the feminization of migration is likely to affect future amounts of remittances, the size of diaspora externalities and the structure of activities in source countries. In this report, women are shown to send remittances over longer time periods, to send larger amount to distant family members and have different impacts on household expenditures at origin. In a study on South Africa, Collinson (2003) showed that employed men remit 25 percent less than employed women. Regarding the determinants of migration, it is also argued that women and men do not respond to push and pull factors with

\footnotetext{
${ }^{5}$ In the same vein, Klasen (1999) or Dollar and Gatti (1999) demonstrated that gender inequality acts as a significant constraint on growth in cross-country regressions, a result confirmed by Blackden et al. (2006) in the case of sub-Saharn Africa.
} 
the same intensity. Social networks are usually seen as more important for women who rely more strongly on relatives and friends for help, information, protection and guidance at destination. Without a gendered assessment of the brain drain, it is obviously impossible to conduct a complete analysis of these issues.

In this paper, we build on the DM06 data set, update the data using new sources, homogenize 1990 and 2000 concepts, and introduce the gender breakdown. We provide revised stocks and rates of emigration by level of schooling and gender. Our gross data reveal that the share of women in the skilled immigrant population increased in almost all OECD destination countries between 1990 and 2000. Consequently, for the vast majority of source regions, the growth rates of skilled female emigrants were always bigger than the growth rates obtained for unskilled women or skilled men. The evolution was particularly in the least developed countries. This feminization of the South-North brain drain mostly reflects gendered changes in the supply of education. We show that the cross-country correlation between emigration stocks of women and men is extremely high (about 97 percent), with women's numbers slightly below men's ones. However, these skilled female migrants are drawn from a much smaller population. Hence, in relative terms, the correlation in rates (88 percent) is much lower than in stocks. On average, women's brain drain is 17 percent above men's. This gender gap in skilled emigration rate is strongly correlated with the gender gap in educational attainment of the source population, reflecting unequal access to education. Equating men and women's educational attainment at origin would strongly reduce the gender gap in skilled migration.

The remainder of this paper is organized as follows. Section 2 provides a brief survey of existing data sets on the brain drain. Section 3 then describes our methodology and presents the measure of emigrant stock in 1990 and 2000. Section 4 analyzes emigration rates. Section 5 summarizes the main results.

\section{Background}

The first serious effort to put together harmonized international data set on migration rates by education level was by Carrington and Detragiache (1998, 1999). They used US 1990 Census data and other OECD statistics on international migration to construct estimates of emigration rates at three education levels for 61 developing countries (including 24 African countries). Adams (2003) used the same technique to build estimates for 24 countries in 2000. Although Carrington and Detragiache's study initiated new debates on skilled migration, their estimates suffer from a number of limitations. The two most important ones were: i) they transposed the education structure of the US immigration to the immigration to the other OECD countries (transposition problem); ii) immigration to EU countries was estimated based on OECD statistics reporting the number of immigrants for the major emigration countries only, which led to underestimate immigration from small countries (under reporting problem). 
Docquier and Marfouk (2006) generalized this work and provided a comprehensive data set on international skilled emigration to the OECD. The construction of the database relies on three steps: i) collection of Census and register information on the structure of immigration in all OECD countries (this solves the transposition and under reporting problems noted for Carrington Detragiache); (ii) summing up over source countries allows for evaluating the stock of immigrants from any given sending country to the OECD area by education level, and iii) comparing the educational structure of emigration to that of the population remaining at home, which allows for computing emigration rates by educational attainment in 1990 and 2000 .

The DM06 data relies on assumptions, some of which were relaxed in a couple of extensions. Most of these extensions required additional assumptions but confirmed, to a large extent, the reliability of using DM06 data in descriptive analysis and empirical regressions.

- First, with only two points in time, DM06 does not give a precise picture of the long-run trends in international migration. To remedy this problem, Defoort (2006) computes skilled emigration stocks and rates from 1975 to 2000 (one observation every 5 years). She used the same methodology as in DM06 but only focuses on the six major destination countries (USA, Canada, Australia, Germany, UK and France). She shows that, at the world level or at the level of developing countries as a whole, the average skilled migration rate has been extremely stable over the period. This suggests that the heterogeneity in the brain drain is mostly driven by the cross-section dimension, thus reinforcing the value of the DM06 cross-country data set based on a much more comprehensive set of destination countries.

- Second, counting all foreign born individuals as immigrants independently of their age at arrival, DM06 does not account for whether education has been acquired in the home or in the host country. Controlling for the country of training can be important when dealing with specific issues such as the fiscal cost of the brain drain. Beine, Docquier and Rapoport (2006) use immigrants' age of entry as a proxy for where education has been acquired and propose alternative measures of the brain drain by defining skilled immigrants as those who left their home country after age 22, 18 or 12 . Data on age of entry are collected in a dozen countries. For OECD countries where such data cannot be obtained, Beine et al. estimated the age-of-entry structure using a gravity model. They found that corrected skilled emigration rates are highly correlated to those reported in $\mathrm{DM}_{06}{ }^{6}$.

- Third, general emigration rates may hide important occupational shortages (e.g. among engineers, teachers, physicians, nurses, IT specialists, etc). In

\footnotetext{
${ }^{6}$ Regressing corrected rates on uncorrected rates gives $R^{2}$ of $0.9775,0.9895$ and 0.9966 for $\mathrm{J}=22,18,12$.
} 
poor countries, shortages are particularly severe in the medical sector where the number of physicians per 1,000 inhabitants is extremely low. Clemens and Pettersson (2006), and Docquier and Bhargava (2006) provided data on the medical brain drain. The elasticity of medical brain drain rates (as measured by Docquier and Bhargava) to DM06 general rates amounts to $0.44\left(R^{2}=0.39\right)$. Many observations are far from the overall trend. This suggests that the general brain drain may not reveal important aspects of occupational heterogeneity.

In this literature, the gender dimension has been largely disregarded. An exception is a paper by Dumont, Martin and Spielvogel (2007) which relies on a similar methodology than the one used here and analyze emigration rates by gender and educational level from about 75 countries. Compared to this study, we use a slightly different definition of high-skill migration (including all post-secondary levels, even those with one year of US college), and rely on plausible estimates of the structure of the adult population in countries where human capital indicators are missing. We repeat the exercise for 1990 and 2000, thus shedding light on the recent feminization of the brain drain. We provide emigration stocks and rates for 195 countries in 1990 and 2000. Our data set can be used to capture the recent trend in women's brain drain, as well as to analyze its causes and consequences for developing countries.

\section{$3 \quad$ Emigration stocks by education level and gender}

This section describes the methodology and data sources used to compute emigration stocks by educational attainment and gender for each source country in 1990 and 2000. Then we discuss the main insights.

\subsection{Methodology and data sources}

It is well documented that statistics provided by source countries do not provide a realistic picture of emigration. When available, which is very rare, they are incomplete and imprecise. Whilst detailed immigration data are not easy to collect on an homogeneous basis, information on emigration can only be captured by aggregating consistent immigration data collected in receiving countries, where information about the birth country, gender and education of natives and immigrants is available from national population censuses and registers (or samples of them). More specifically, the receiving country $j$ 's census usually identifies individuals on the basis of age, gender $g$, country of birth $i$, and skill level $s$. Our method consists in collecting (census or registers) gender-disaggregated data from a large set of receiving countries, with the highest level of detail on birth countries and three levels of educational attainment: $s=h$ for high-skilled, $s=m$ for medium-skilled and $s=l$ for low-skilled. Let $M_{t, g, s}^{i, j}$ denote the stock of adults $25+$ born in $j$, of gender $g$, skill $s$, living in country $j$ at time $t$. 
Table 1 describes our data sources. For countries where population registers (mainly Scandinavian countries) are used, data is based on the whole population. In countries where Census data are used, statistics are either based on the whole population (Australia, New Zealand, Belgium, etc.) or on a sample of it (e.g. 25 percent in France, etc.). In some cases, we combine comprehensive register data on the numbers of adult males and females, but use sample data to estimate the educational structure (the UK is estimated on 10 percent of the population; in Germany, the microcensus is based on 1 percent of the population). The education structure is sometimes given by region or groups of countries; we then assume a constant share within the region. In a couple of countries, we use household and labor force surveys to estimate the educational structure. Finally, we also use IPUMS International data set for Mexico, Spain and the United States.

Aggregating these numbers over destination countries $j$ gives the stock of emigrants from country $i: M_{t, g, s}^{i}=\sum_{j} M_{t, g, s}^{i, j}$. This is the method used in DM06, without gender breakdown.

By focusing on census and register data, our methodology badly captures illegal immigration for which systematic statistics by education level and country of birth are not available ${ }^{7}$, except in the USA. Demographic evidence indicates most US illegal residents are captured in the census. However, there is no accurate data about the educational structure of these illegal migrants. Hence, we probably underestimate the number of unskilled in the immigrant population, assuming that most illegal immigrants are uneducated. Nevertheless, this limitation should not significantly distort our estimates of the migration rate of highly-skilled workers.

\footnotetext{
${ }^{7}$ Hatton and Williamson (2002) estimate that illegal immigrants residing in OECD countries represent 10 to 15 percent of the total stock.
} 
Table 1. Data sources

\begin{tabular}{|c|c|c|c|}
\hline Receiving country & Definition & 1990 & 2000 \\
\hline Australia & Foreign Born & Australian Bureau of Statistics & Australian Bureau of Statistics \\
\hline Austria & Foreign Born & Statistik Austria & Statistik Austria \\
\hline Belgium & Foreign Born & Institut National de Statistiques & Institut National de Statistiques \\
\hline Canada & Foreign Born & Statistics Canada & Statistics Canada \\
\hline Czech Rep & Foreign Born & Estimates $(\mathrm{a}, \mathrm{c})$ & Czech Statistical Office \\
\hline Denmark & Foreign Born & Statistics Denmark & Statistics Denmark \\
\hline Finland & Foreign Born & Statistics Finland & Statistics Finland \\
\hline France & Foreign Born & INSEE & INSEE \\
\hline Germany & Foreign citizens & Microsensus + Federal Statistical Office & Microsensus + Federal Statistical Office \\
\hline Greece & Foreign Born & Estimates $(\mathrm{a}, \mathrm{c})$ & National Statistical Service of Greece \\
\hline Hungary & Foreign citizens & Estimates $(\mathrm{a}, \mathrm{c})$ & IPUMS-International \\
\hline Iceland & Foreign Born & Statistics Iceland + Estimates & Statistics Iceland + Estimates (c) \\
\hline Ireland & Foreign Born & Central Statistics Office Ireland & Central Statistics Office Ireland \\
\hline Italy & Foreign citizens & Estimates $(\mathrm{a}, \mathrm{c})$ & Istituto Nazionale di Statistica \\
\hline Japan & Foreign citizens & Estimates $(b, c)$ & Statistics Japan + Estimates (c) \\
\hline Korea & Foreign citizens & Estimates $(b, c)$ & Statistics Korea + Estimates (c) \\
\hline Luxemburg & Foreign Born & STATEC Luxemburg & STATEC Luxemburg \\
\hline Mexico & Foreign Born & IPUMS-International & IPUMS-International \\
\hline Netherland & Foreign Born & Statistics Netherlands + Estimates (c) & Statistics Netherlands + Estimates (c) \\
\hline New Zealand & Foreign Born & Statistics New Zealand & Statistics New Zealand \\
\hline Norway & Foreign Born & Statistics Norway & Statistics Norway \\
\hline Poland & Foreign Born & Estimates $(\mathrm{a}, \mathrm{c})$ & Poland Statistics \\
\hline Portugal & Foreign Born & Instituto Nacional de Estatistica & Instituto Nacional de Estatistica \\
\hline Slovak Rep & Foreign Born & Statistical Office of the Slovak Republic & Statistical Office of the Slovak Republic \\
\hline Spain & Foreign Born & Estimates $(b, c)$ & IPUMS-International \\
\hline Sweden & Foreign Born & Statistics Sweden & Statistics Sweden \\
\hline Switzerland & Foreign Born & Swiss Statistics & Swiss Statistics \\
\hline Turkey & Foreign Born & Turkish Statistical Institute & Turkish Statistical Institute \\
\hline United Kingdom & Foreign Born & Office for National Statistics & Office for National Statistics \\
\hline United States & Foreign Born & Bureau of Census + IPUMS & Bureau of Census + IPUMS \\
\hline
\end{tabular}

(a) Immigration stocks are estimated using the SOPEMI data set by country of citizenship (rescaled using the foreign-born/foreign citizens ratio in 2000)

(b) Immigration stocks are estimated using the United Nations Population Division data set

(c) Education levels are estimated using household survey or the average change in education attainment observed in other OECD countries 
In this paper, we rely on the same principles as in DM06 and turn our attention to the homogeneity and the comparability of the data. This induces a couple of methodological choices:

- In what follows, the term "source country" usually designates independent states. We distinguish 195 source countries: 191 UN member states, Holy See, Taiwan, Hong Kong, Macao and Palestinian Territories. We aggregate North and South Korea, West and East Germany and the Democratic Republic and the Republic of Yemen. We consider the same set of source countries in 1990 and 2000, although some of them had no legal existence in 1990 (before the secession of the Soviet block, former Yugoslavia, former Czechoslovakia and the German and Yemen reunifications) or became independent after January 1, 1990 (Eritrea, East-Timor, Namibia, Marshall Islands, Micronesia, Palau). In these cases, the 1990 estimated stock is obtained by multiplying the 1990 value for the pre-secession state by the 2000 country share in the stock of immigrants (the share is gender- and skill-specific).

- The set of receiving countries is restricted to OECD nations. We thus focus on the structure of South-North and North-North migration. Generally speaking, the skill level of immigrants in non-OECD countries is expected to be very low, except in a few countries such as South Africa (1.3 million immigrants in 2000), the six member states of the Gulf Cooperation Council (9.6 million immigrants in Saudi Arabia, United Arab Emirates, Kuwait, Bahrain, Oman and Qatar), some Eastern Asian countries (4 million immigrants in Hong-Kong and Singapore only). According to their census and survey data, about 17.5 percent of adult immigrants are tertiary educated in these countries (17 percent in Bahrain, 17.2 percent in Saudi Arabia, 14 percent in Kuwait, 18.7 percent in South Africa). Considering that children constitute about 25 percent of the immigration stock, we estimate the number of educated workers at 1.9 million in these countries. The number of educated immigrants in the rest of the world lies between 1 and 4 million (if the average proportion of educated immigrants among adults lies between 2.5 and 10 percent). This implies that focusing on OECD countries, we should capture a large fraction of the world-wide educated migration (about 90 percent). Nevertheless, we are aware that by disregarding non-OECD immigration countries, we probably underestimate the brain drain for several developing countries (such as Egypt, Sudan, Jordan, Yemen, Pakistan or Bangladesh in the neighborhood of the Gulf states, Botswana, Lesotho, Namibia, Swaziland and Zimbabwe, etc.). Incorporating data collected from selected non-OECD countries could refine the data set. To allow comparisons between 1990 and 2000, we consider the same 30 receiving countries in 1990 and 2000. Consequently, Czechoslovakia, Hungary, Korea, Poland and Mexico are considered as receiving countries in 1990 despite the fact that they were not members of the OECD. 
- We only consider the adult population aged 25 and over. This excludes students who temporarily emigrate to complete their education. In addition, as it will appear in the next section, it will allow us to compare the numbers of migrants with data on educational attainment in source countries. It is worth noticing that we have no systematic information on the age of entry. It is therefore impossible to distinguish between immigrants who were educated at the time of their arrival and those who acquired education after they settled in the receiving country; for example, Mexican-born individuals who arrived in the US at age 5 or 10 and graduated from US high-education institutions are counted as highly-skilled immigrants. As mentionned above, Beine et al (2007a) provided corrected measures by age of entry and found a very high correlation with the uncorrected numbers.

- Migration is defined on the basis of the country of birth rather than citizenship. Whilst citizenship characterizes the foreign population, the "foreign-born" concept better captures the decision to emigrate ${ }^{8}$. Usually, the number of foreignborn is much higher than the number of foreign citizens (twice as large in countries such as Hungary, the Netherlands, and Sweden $)^{9}$. Another reason is that the concept of country of birth is time invariant (contrary to citizenship which changes with naturalization) and independent of the changes in policies regarding naturalization ${ }^{10}$. The number of foreign-born can be obtained for a large majority of OECD countries although in a limited number of cases the national census only gives immigrants' citizenship (Germany, Hungary, Italy, Japan and Korea). It is worth noting that the concept of foreign born is not fully homogeneous across OECD countries. In most receiving countries, foreign born are individual born abroad with foreign citizenship at birth. In a couple of countries, foreign born means "overseas-born", i.e. an individual simply born abroad.

- We distinguish three levels of education. Medium-skilled migrants are those with upper-secondary education completed. Low-skilled migrants are those with less than upper-secondary education, including those with lower-secondary and primary education or those who did not go to school. High-skilled migrants are those with post-secondary education (this includes those with one year of post-secondary education in the US). This assumption is compatible with Barro and Lee's human capital indicators (based on the 1976-ISCED classification).

\footnotetext{
${ }^{8}$ In some receiving countries such as Germany, immigrants' children (i.e. the second generation) usually keep their foreign citizenship.

${ }^{9}$ By contrast, in other OECD countries with a restricted access to nationality (such as Japan, Korea, and Switzerland), the foreign population is important (about 20 percent in Switzerland).

${ }^{10}$ The OECD statistics report that 14.4 million foreign born individuals were naturalized between 1991 and 2000. Countries with a particularly high number of acquisitions of citizenship are the US (5.6 million), Germany (2.2 million), Canada (1.6 million), and Australia and France (1.1 million).
} 
Some migrants did not report their education level. As in DM06, we classify these unknowns as low-skilled migrants ${ }^{11}$. Educational categories are built on the basis of country specific information and are compatible with human capital indicators available for all sending countries. A mapping between the country educational classification is sometimes required to harmonize the data ${ }^{12}$.

\subsection{Women's share in OECD immigration}

According to our estimates, the average share of women in the OECD immigrant population decreased from 51.6 to 50.6 percent between 1990 and 2000. Countryspecific shares range from 41.8 in Iceland to 59.8 in Poland . It amounts to 53 percent in the United Kingdom, 52.3 in Canada, 51 in the United States, 49.5 in France and 46.2 in Germany. This share increased or stagnated in almost all countries over the 1990s. The only significant decreases are observed in Belgium (-3.8 percentage points) and Ireland (-2.8). Remarkable increases were observed in Austria $(+11.3$ percentage points), Portugal $(+6.4)$ and, to a lower extent, in Turkey, Korea, Japan or Switzerland.

The average share of women in the OECD skilled immigrant population increased from 48.0 to 49.7 percent between 1990 and 2000. Country-specific shares range from 39.8 percent in Iceland to 56.4 in Poland. It amounts to 50.2 percent in the United Kingdom, 49.9 in the United States, 48.4 in Canada (the only country where there are more skilled women than skilled men), 46.6 in France and 45.2 in Germany. This share increased in almost all countries except in Belgium (-2.1) and Spain (1.4). Remarkable increases in female share were observed in the Czech Rep $(+18.6$ percentage points), Finland $(+9.2)$ and Turkey $(+9.1)$.

\footnotetext{
${ }^{11}$ Country specific data by occupation reveal that the occupational structure of those with unknown education is very similar to the structure of low-skilled workers (and strongly different from that of high-skilled workers). See Debuisson et al. (2004) on Belgium data.

${ }^{12}$ For example, Australian data mix information about the highest degree and the number of years of schooling.
} 
Figure 1.1. Women's share in total immigration

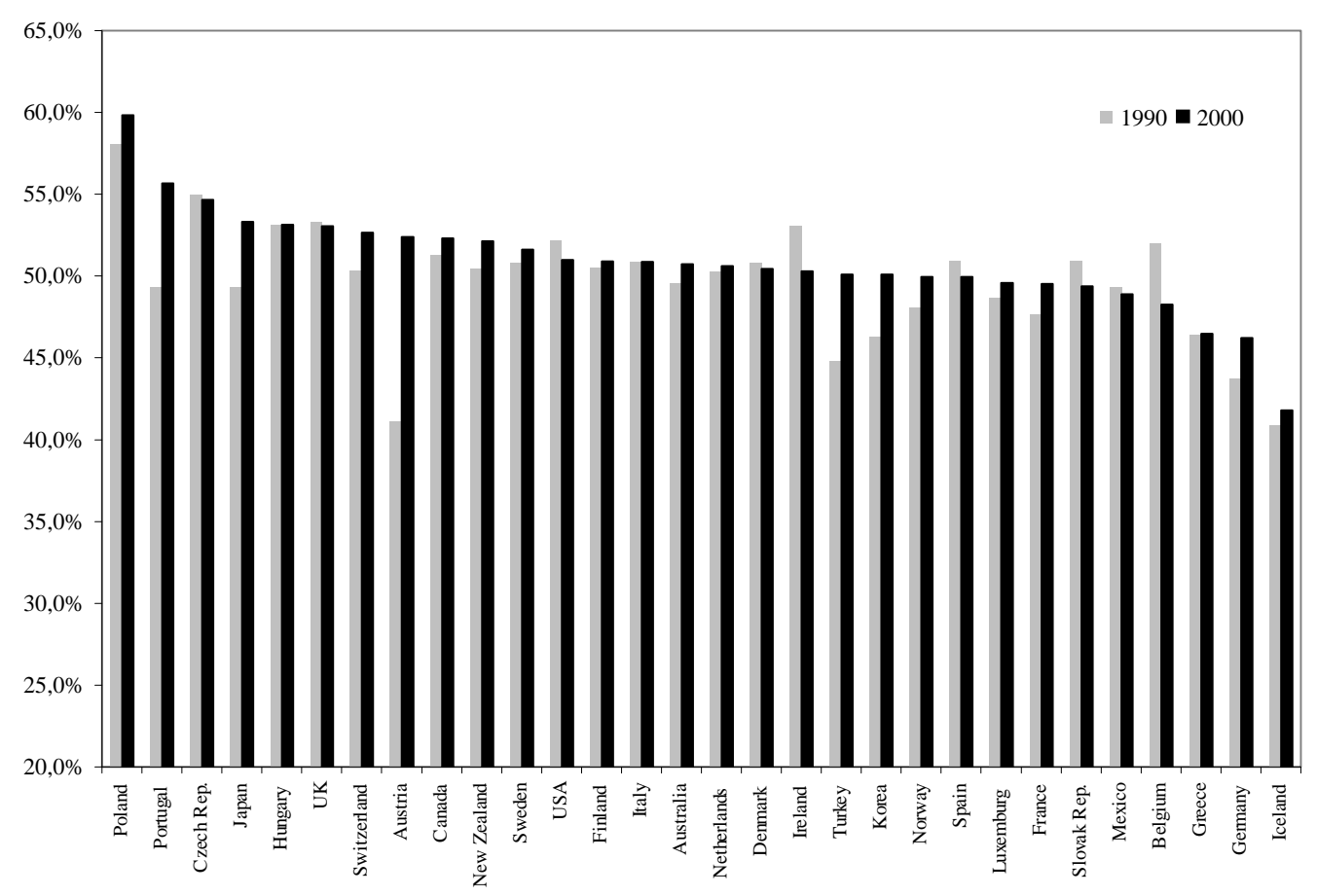

Figure 1.2. Women's share in skilled immigration

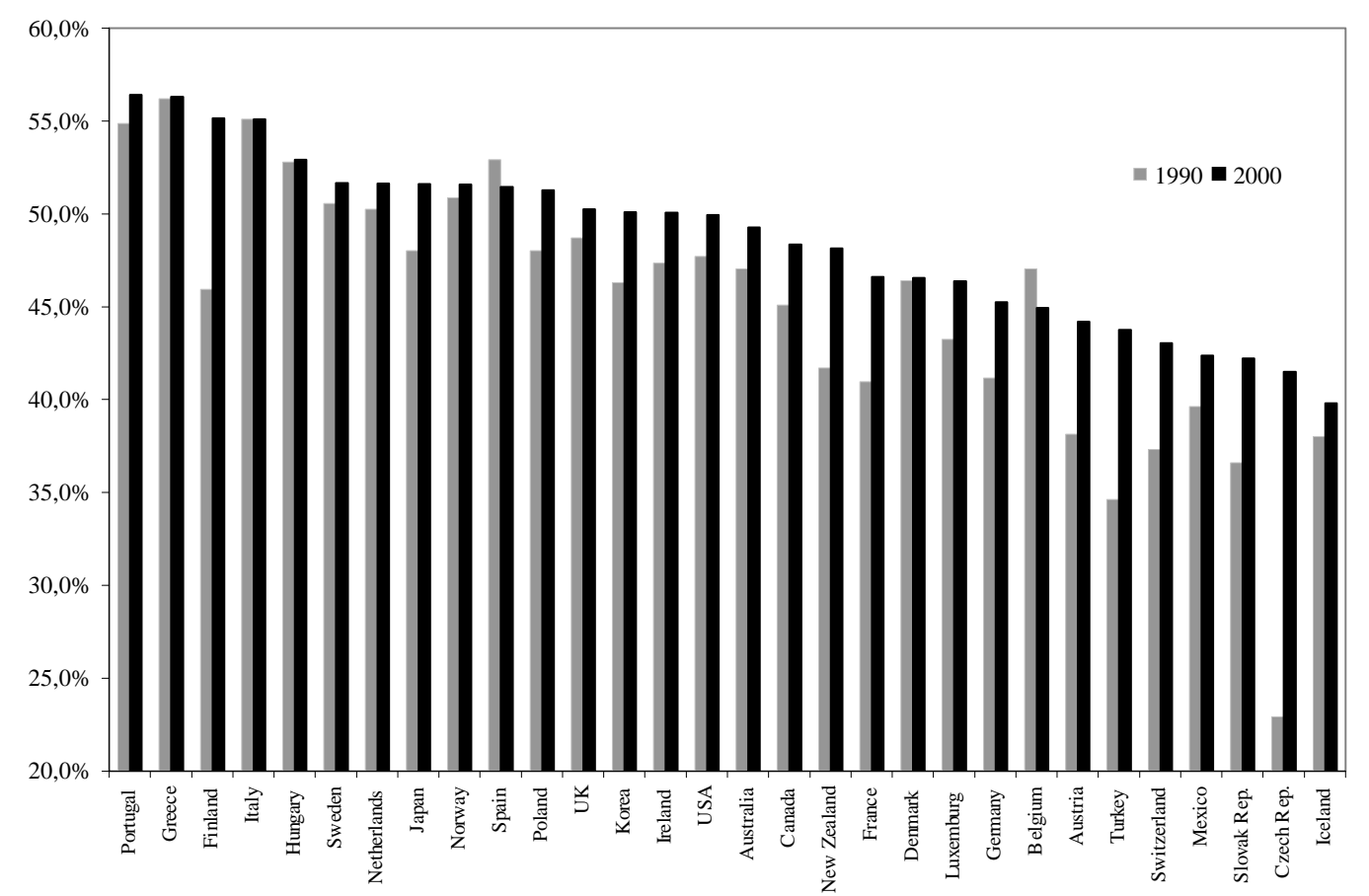




\subsection{Stocks by education level and gender}

Tables 2.1 and 2.2 respectively gives the emigration stocks for 1990 and 2000 . We distinguish total, low-skill and high-skill emigration stocks, the medium skilled can be easily obtained by substraction. Although the data set reveals specific information by country, we only report here data by country group. We consider income groups (following the World Bank classification), regional groups and groups of developing countries as defined in the UN classification, as well as a couple of groups of particular interest (OECD members, large countries with population above 75 million, subSaharan Africa, Latin America and the Caribbean, Middle East and Northern Africa and Islamic countries).

On the whole, we record 41.7 million immigrants aged $25+$ and 58.2 million in 2000. The female share in adult OECD immigration was stable over the decade $(50.6$ percent in 1990 and 50.9 percent in 2000). These numbers are (for adults aged 25 and over) in line with the UNDP global numbers reported for the OECD countries $(50.2$ and 50.6 for these two years). However, the women's share varies across education level. The share in unskilled migration is above 51 percent (it decreased from 51.5 to 51.1 percent during the decade). The share in skilled migration is below 50 percent but strongly increased between 1990 and 2000 (from 46.7 to 49.3 percent).

The number of skilled women immigrants increased by 74 percent (from 5.8 to about 10.1 million). The rise was important for developing countries (both middle and low-income) where the number of skilled women emigrants was multiplied by 2.1 (+110 percent). Such an increase is in women skilled emigration is observed in every source region and is mainly due to the fact that women's rise in schooling level was more rapid than men's rise (supply effect). To a lesser extent, this also reflects the fact that skilled women are increasingly on the move. Indeed, as it will appear from the next section, the female skilled adult population increased by 67.9 percent at the world level and 83 percent in developing countries.

Figure 2 compares the average annual growth rates of women's total and skilled emigration stock and men's skilled emigration stock by region over the decade. In almost all regions the growth rate for skilled women is always bigger than for all women or skilled men. The evolution was particularly strong for migrants from the least developed countries, especially from low-income countries. The growth rate observed for Central and Southern Asia, sub-Saharan Africa and Central America are particularly high.

Table 3 reports countries sending the largest stocks of migrants to the OECD. In absolute terms (number of educated emigrants), the largest countries are obviously strongly affected by the brain drain. The elasticity of emigration stock to population size amounts to 63.2 percent, revealing that small countries are relatively more affected that large countries. The five largest diasporas (all education categories) originate from Mexico (6.434 million), United Kingdom (2.990 million), Italy (2.337 million), Germany (2.299 million) and Turkey (1.942 million). Eight other countries have diaspora above 1 million: India, the Philippines, China, Vietnam, Portugal, Ko- 
rea, Poland and Morocco. In most of these countries, the women's share varies from 48 to 52 percent. However, women's share is particularly high for the Philippines (62.2 percent), Germany (57.4), Korea and Poland (around 56 percent).

Focusing on skilled emigrants, the ranking unsurpisingly shows that rich countries with highly educated population have better educated diasporas. The elasticity of skilled emigration to population size at origin amounts to 65.7 percent. The largest skilled diasporas originate from the United Kingdom (1.487 million), the Philippines (1.111 million) and India (1.034 million). Germany and Mexico send more than 0.9 million skilled natives abroad. Four other countries have diasporas above 0.5 million: China, Korea, Canada and Vietnam. In these top-countries, the share of women among skilled migrants is large in Jamaica (62.1 percent), the Philippines (60.3) and other countries such as Japan, Russia, Ukraine, Poland and Colombia.

Figure 2. Annual average growth rate of total/skilled stock of emigrants Data by region (1990-2000)

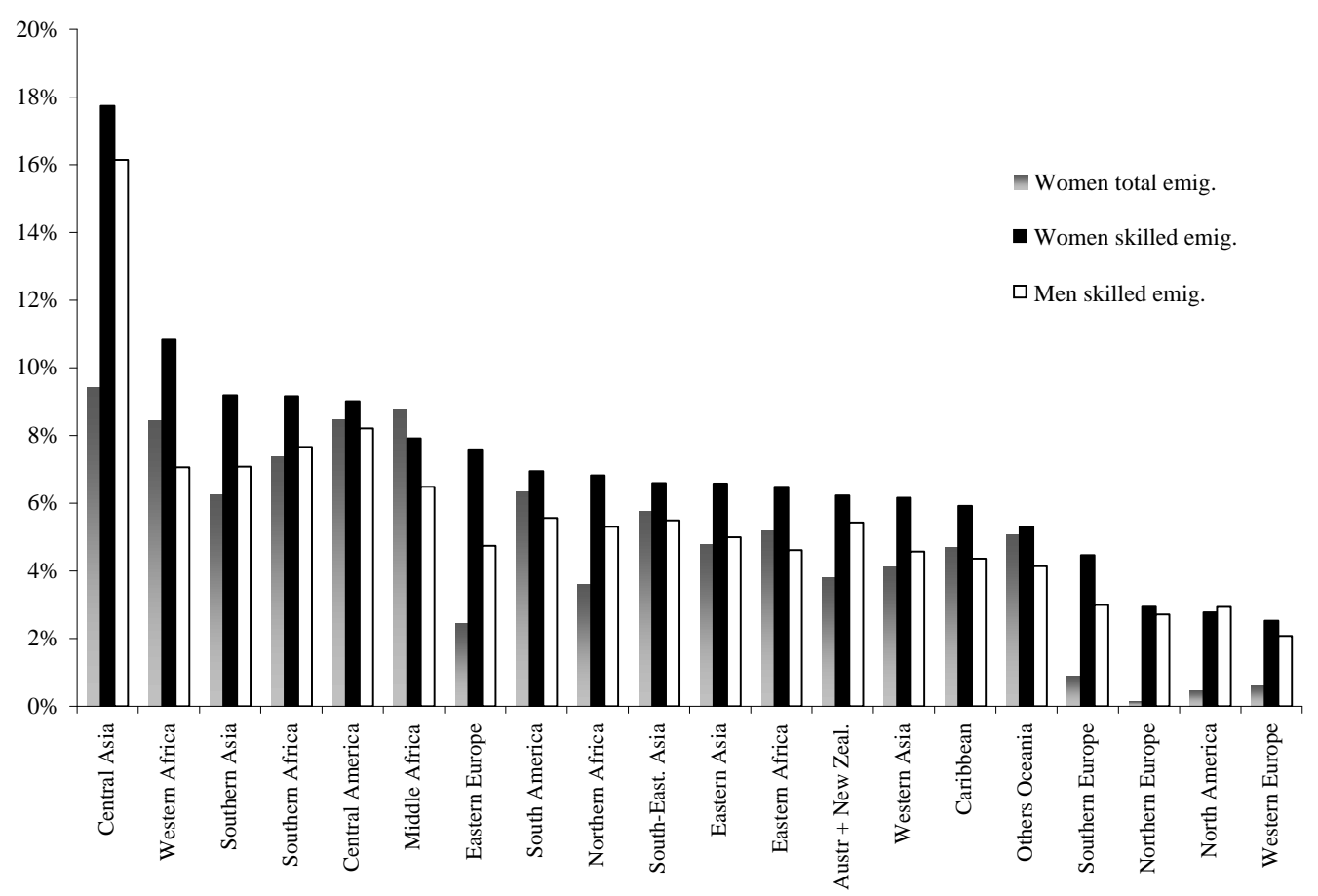


Table 2.1. Stock of emigrants by education and gender in 1990 (in thousands)

\begin{tabular}{|c|c|c|c|c|c|c|c|c|c|c|c|c|}
\hline & \multicolumn{4}{|c|}{ Total migration (All education levels) } & \multicolumn{4}{|c|}{ Unskilled migration (Less than secondary) } & \multicolumn{4}{|c|}{ Skilled migration (post-secondary) } \\
\hline & Both & Men & Women & $\%$ & Both & Men & Women & $\%$ & Both & Men & Women & $\%$ \\
\hline World (a) & 41705 & 20615 & 21090 & $50,6 \%$ & 20414 & 9891 & 10523 & $51,5 \%$ & 12501 & 6668 & 5833 & $46,7 \%$ \\
\hline $\begin{array}{l}\text { World Bank Income Classification (b) } \\
\text { High-income countries }\end{array}$ & 18046 & 8496 & 9550 & $52.9 \%$ & 7991 & 3680 & 4310 & $53.9 \%$ & 5749 & 2952 & 2797 & 4870 \\
\hline Upper-Middle-income countries & 9125 & 4717 & 4408 & $48,3 \%$ & 5433 & 2766 & 2667 & $49,1 \%$ & 2027 & 1114 & 913 & $\begin{array}{l}48,7 \% \\
45,0 \%\end{array}$ \\
\hline Lower-Middle-income countries & 9843 & 4898 & 4945 & $50,2 \%$ & 4753 & 2344 & 2409 & $50,7 \%$ & 3144 & 1639 & 1505 & $47,9 \%$ \\
\hline Low-income countries & 3507 & 1915 & 1592 & $45,4 \%$ & 1565 & 772 & 793 & $50,7 \%$ & 1317 & 822 & 495 & $37,6 \%$ \\
\hline United Nations Classification (c) & & & & & & & & & & & & \\
\hline Least Developed Countries & 1354 & 748 & 606 & $44,8 \%$ & 714 & 364 & 350 & $49,0 \%$ & 412 & 258 & 153 & $37,2 \%$ \\
\hline Landlocked Developing countries & 783 & 420 & 362 & $46,3 \%$ & 373 & 191 & 182 & $48,7 \%$ & 264 & 152 & 112 & $42,3 \%$ \\
\hline $\begin{array}{l}\text { Small Island Developing countries } \\
\text { United Nations Classification (d) }\end{array}$ & 2643 & 1231 & 1411 & $53,4 \%$ & 1149 & 529 & 620 & $54,0 \%$ & 918 & 448 & 471 & $51,2 \%$ \\
\hline Africa & 2837 & 1676 & 1162 & $40,9 \%$ & 1717 & 994 & 723 & $42,1 \%$ & 724 & 464 & 260 & $35,9 \%$ \\
\hline Eastern Africa & 516 & 268 & 248 & $48,0 \%$ & 212 & 97 & 115 & $54,2 \%$ & 204 & 123 & 81 & $39,6 \%$ \\
\hline Middle Africa & 103 & 60 & 43 & $41,6 \%$ & 42 & 22 & 20 & $47,7 \%$ & 38 & 25 & 13 & $34,0 \%$ \\
\hline Northern Africa & 1671 & 1021 & 650 & $38,9 \%$ & 1226 & 737 & 489 & $39,9 \%$ & 259 & 173 & 86 & $33,4 \%$ \\
\hline Southern Africa & 135 & 66 & 70 & $51,3 \%$ & 30 & 12 & 17 & $58,4 \%$ & 79 & 43 & 36 & $45,8 \%$ \\
\hline Western Africa & 412 & 261 & 151 & $36,7 \%$ & 208 & 126 & 82 & $39,4 \%$ & 143 & 100 & 44 & $30,4 \%$ \\
\hline Americas & 8439 & 4080 & 4359 & $51,7 \%$ & 4151 & 2048 & 2103 & $50,7 \%$ & 2641 & 1302 & 1340 & $50,7 \%$ \\
\hline Caribbean & 1954 & 905 & 1050 & $53,7 \%$ & 839 & 389 & 450 & $53,7 \%$ & 693 & 331 & 362 & $52,3 \%$ \\
\hline Central America & 3486 & 1826 & 1660 & $47,6 \%$ & 2412 & 1273 & 1139 & $47,2 \%$ & 604 & 321 & 283 & $46,8 \%$ \\
\hline South America & 1574 & 723 & 851 & $54,1 \%$ & 492 & 211 & 281 & $57,1 \%$ & 628 & 315 & 313 & $49,8 \%$ \\
\hline North America & 1424 & 625 & 798 & $56,1 \%$ & 408 & 176 & 233 & $57,0 \%$ & 717 & 335 & 382 & $53,3 \%$ \\
\hline Asia & 9402 & 4737 & 4664 & $49,6 \%$ & 3956 & 1894 & 2062 & $52,1 \%$ & 3781 & 2067 & 1714 & $45,3 \%$ \\
\hline Central Asia & 35 & 16 & 19 & $53,7 \%$ & 19 & 9 & 10 & $51,8 \%$ & 8 & 4 & 4 & $54,2 \%$ \\
\hline Eastern Asia & 2645 & 1220 & 1425 & $53,9 \%$ & 789 & 327 & 462 & $58,5 \%$ & 1282 & 661 & 621 & $48,4 \%$ \\
\hline Southern Asia & 1961 & 1102 & 859 & $43,8 \%$ & 732 & 370 & 362 & $49,5 \%$ & 853 & 540 & 312 & $36,6 \%$ \\
\hline South-Eastern Asia & 2577 & 1172 & 1405 & $54,5 \%$ & 959 & 406 & 553 & $57,6 \%$ & 1191 & 575 & 616 & $51,7 \%$ \\
\hline Western Asia & 2184 & 1227 & 957 & $43,8 \%$ & 1457 & 782 & 675 & $46,3 \%$ & 447 & 287 & 160 & $35,9 \%$ \\
\hline Europe & 19318 & 9281 & 10038 & $52,0 \%$ & 9788 & 4567 & 5221 & $53,3 \%$ & 4869 & 2581 & 2288 & $47,0 \%$ \\
\hline Eastern Europe & 3615 & 1699 & 1917 & $53,0 \%$ & 1895 & 830 & 1065 & $56,2 \%$ & 867 & 469 & 398 & $45,9 \%$ \\
\hline Northern Europe & 4513 & 2072 & 2441 & $54,1 \%$ & 1513 & 663 & 850 & $56,2 \%$ & 1564 & 796 & 767 & $49,1 \%$ \\
\hline Southern Europe & 6948 & 3663 & 3284 & $47,3 \%$ & 4763 & 2427 & 2336 & $49,0 \%$ & 965 & 572 & 393 & $40,8 \%$ \\
\hline Western Europe & 4242 & 1846 & 2395 & $56,5 \%$ & 1617 & 647 & 970 & $60,0 \%$ & 1473 & 744 & 729 & $49,5 \%$ \\
\hline Oceania & 524 & 252 & 273 & $52,0 \%$ & 129 & 59 & 71 & $54,6 \%$ & 221 & 114 & 107 & $48,5 \%$ \\
\hline Australia and New Zealand & 383 & 184 & 199 & $52,0 \%$ & 75 & 34 & 41 & $55,1 \%$ & 166 & 85 & 81 & $48,9 \%$ \\
\hline Others Oceania & 141 & 68 & 73 & $51,9 \%$ & 54 & 25 & 29 & $53,8 \%$ & 54 & 29 & 26 & $47,5 \%$ \\
\hline Groups of interest & & & & & & & & & & & & \\
\hline OECD members & 22490 & 10886 & 11603 & $51,6 \%$ & 11513 & 5537 & 5975 & $51,9 \%$ & 6066 & 3157 & 2909 & $48,0 \%$ \\
\hline Large countries $(>75 \mathrm{M})$ & 10766 & 5220 & 5546 & $51,5 \%$ & 4953 & 2366 & 2588 & $52,2 \%$ & 3782 & 1964 & 1818 & $48,1 \%$ \\
\hline Sub-Saharan Africa & 1166 & 655 & 512 & $43,9 \%$ & 491 & 257 & 234 & $47,7 \%$ & 465 & 291 & 174 & $37,4 \%$ \\
\hline LAC countries (e) & 7015 & 3454 & 3561 & $50,8 \%$ & 3743 & 1873 & 1870 & $50,0 \%$ & 1925 & 967 & 958 & $49,8 \%$ \\
\hline MENA countries ( $(\mathrm{f})$ & 2751 & 1652 & 1099 & $40,0 \%$ & 1600 & 930 & 671 & $41,9 \%$ & 748 & 495 & 253 & $33,8 \%$ \\
\hline Islamic countries (g) & 5845 & 3374 & 2471 & $42,3 \%$ & 3624 & 2027 & 1597 & $44,1 \%$ & 1309 & 840 & 469 & $35,8 \%$ \\
\hline
\end{tabular}

(a) In the World total, we include individuals with unknown origin country.

(b) http://web.worldbank.org/WBSITE/EXTERNAL/DATASTATISTICS/0, contentMDK:20420458 menuPK:64133156 pagePK:64133150 piPK:64133175 theSitePK:239419,00.html

(b) http://www.un.org/special-rep/ohrlls/ldc/list.htm; http://www.un.org/special-rep/ohrlls/llde/list.htm; http://www.un.org/special-rep/ohrlls/sid/list.htm

(d) http://unstats.un.org/unsd/methods/m49/m49regin.htm

(e) $\mathrm{LAC}=\mathrm{Cental}$ Anerica + South Anerica + The Caribbean; Sub-Saharan Africa = Africa - Northern Africa

(f) http://web.worldbank.org/WBSITE/EXTERNAL/COUNTRIES/MENAEXT/0,,menuPK:247606 pagePK:146732 piPK:146828 theSitePK:256299, 00.html

(g) http://www.islamic-world.net/countries/index.htm 
Table 2.2. Stock of emigrants by education and gender in 2000 (in thousands)

\begin{tabular}{|c|c|c|c|c|c|c|c|c|c|c|c|c|}
\hline & \multicolumn{4}{|c|}{ Total migration (All education levels) } & \multicolumn{4}{|c|}{ Unskilled migration (Less than secondary) } & \multicolumn{4}{|c|}{ Skilled migration (post-secondary) } \\
\hline & Both & Men & Women & $\%$ & Both & Men & Women & $\%$ & Both & Men & Women & $\%$ \\
\hline World (a) & 58246 & 28623 & 29623 & $50,9 \%$ & 25068 & 12248 & 12820 & $51,1 \%$ & 20442 & 10372 & 10069 & $49,3 \%$ \\
\hline $\begin{array}{l}\text { World Bank Income Classification (b) } \\
\text { High-income countries }\end{array}$ & 19717 & 9302 & 10415 & $52.8 \%$ & 6936 & 3219 & 3717 & $53,6 \%$ & 7911 & 3934 & 3977 & 5030 \\
\hline Upper-Middle-income countries & 15339 & 7858 & 7482 & $48,8 \%$ & 8572 & 4446 & 4126 & $48,1 \%$ & 3729 & 1890 & 1839 & $\begin{array}{l}5,5 \% \\
49,3 \%\end{array}$ \\
\hline Lower-Middle-income countries & 15505 & 7467 & 8037 & $51,8 \%$ & 6432 & 3110 & 3322 & $51,6 \%$ & 5691 & 2762 & 2929 & $51,5 \%$ \\
\hline Low-income countries & 6445 & 3381 & 3064 & $47,5 \%$ & 2290 & 1069 & 1220 & $53,3 \%$ & 2918 & 1683 & 1235 & $42,3 \%$ \\
\hline United Nations Classification (c) & & & & & & & & & & & & \\
\hline Least Developed Countries & 2364 & 1237 & 1127 & $47,7 \%$ & 1049 & 507 & 542 & $51,7 \%$ & 813 & 473 & 340 & $41,8 \%$ \\
\hline Landlocked Developing countries & 1333 & 681 & 652 & $48,9 \%$ & 511 & 248 & 264 & $51,6 \%$ & 524 & 282 & 241 & $46,1 \%$ \\
\hline $\begin{array}{l}\text { Small Island Developing countries } \\
\text { United Nations Classification (d) }\end{array}$ & 4123 & 1874 & 2249 & $54,6 \%$ & 1598 & 730 & 868 & $54,3 \%$ & 1536 & 701 & 835 & $54,4 \%$ \\
\hline Africa & 4352 & 2434 & 1918 & $44,1 \%$ & 2136 & 1168 & 967 & $45,3 \%$ & 1373 & 817 & 556 & $40,5 \%$ \\
\hline Eastern Africa & 812 & 401 & 411 & $50,6 \%$ & 234 & 98 & 136 & $58,2 \%$ & 346 & 194 & 152 & $43,9 \%$ \\
\hline Middle Africa & 214 & 115 & 99 & $46,4 \%$ & 88 & 41 & 47 & $53,3 \%$ & 74 & 47 & 28 & $37,0 \%$ \\
\hline Northern Africa & 2252 & 1326 & 925 & $41,1 \%$ & 1464 & 839 & 625 & $42,7 \%$ & 457 & 289 & 167 & $36,6 \%$ \\
\hline Southern Africa & 272 & 130 & 142 & $52,1 \%$ & 32 & 14 & 19 & $57,7 \%$ & 177 & 90 & 87 & $49,3 \%$ \\
\hline Western Africa & 803 & 462 & 341 & $42,5 \%$ & 318 & 177 & 141 & $44,2 \%$ & 319 & 197 & 122 & $38,2 \%$ \\
\hline Americas & 15493 & 7667 & 7826 & $50,5 \%$ & 7599 & 3916 & 3682 & $48,5 \%$ & 4631 & 2203 & 2428 & $52,4 \%$ \\
\hline Caribbean & 3010 & 1347 & 1663 & $55,3 \%$ & 1155 & 529 & 626 & $54,2 \%$ & 1150 & 507 & 643 & $55,9 \%$ \\
\hline Central America & 8050 & 4301 & 3749 & $46,6 \%$ & 5344 & 2899 & 2445 & $45,8 \%$ & 1377 & 707 & 670 & $48,6 \%$ \\
\hline South America & 2899 & 1322 & 1577 & $54,4 \%$ & 818 & 363 & 455 & $55,6 \%$ & 1155 & 541 & 613 & $53,1 \%$ \\
\hline North America & 1534 & 697 & 837 & $54,6 \%$ & 282 & 126 & 156 & $55,4 \%$ & 950 & 448 & 502 & $52,9 \%$ \\
\hline Asia & 15198 & 7405 & 7794 & $51,3 \%$ & 5435 & 2525 & 2910 & $53,5 \%$ & 7002 & 3595 & 3408 & $48,7 \%$ \\
\hline Central Asia & 82 & 37 & 46 & $55,7 \%$ & 26 & 12 & 14 & $52,7 \%$ & 40 & 17 & 23 & $57,6 \%$ \\
\hline Eastern Asia & 4123 & 1845 & 2278 & $55,3 \%$ & 1046 & 435 & 611 & $58,4 \%$ & 2251 & 1077 & 1174 & $52,2 \%$ \\
\hline Southern Asia & 3472 & 1896 & 1575 & $45,4 \%$ & 1054 & 513 & 541 & $51,3 \%$ & 1823 & 1071 & 752 & $41,2 \%$ \\
\hline South-Eastern Asia & 4354 & 1889 & 2464 & $56,6 \%$ & 1347 & 538 & 809 & $60,0 \%$ & 2148 & 981 & 1167 & $54,3 \%$ \\
\hline Western Asia & 3168 & 1737 & 1431 & $45,2 \%$ & 1962 & 1026 & 936 & $47,7 \%$ & 740 & 448 & 292 & $39,4 \%$ \\
\hline Europe & 21170 & 10120 & 11049 & $52,2 \%$ & 8901 & 4159 & 4742 & $53,3 \%$ & 6864 & 3467 & 3397 & $49,5 \%$ \\
\hline Eastern Europe & 4436 & 1990 & 2445 & $55,1 \%$ & 1687 & 712 & 975 & $57,8 \%$ & 1571 & 745 & 826 & $52,6 \%$ \\
\hline Northern Europe & 4645 & 2172 & 2474 & $53,2 \%$ & 1130 & 494 & 636 & $56,3 \%$ & 2066 & 1040 & 1026 & $49,6 \%$ \\
\hline Southern Europe & 7494 & 3905 & 3589 & $47,9 \%$ & 4682 & 2374 & 2308 & $49,3 \%$ & 1377 & 768 & 609 & $44,2 \%$ \\
\hline Western Europe & 4595 & 2053 & 2542 & $55,3 \%$ & 1402 & 579 & 823 & $58,7 \%$ & 1850 & 914 & 936 & $50,6 \%$ \\
\hline Oceania & 791 & 382 & 410 & $51,8 \%$ & 159 & 76 & 83 & $52,3 \%$ & 379 & 187 & 192 & $50,7 \%$ \\
\hline Australia and New Zealand & 564 & 274 & 290 & $51,4 \%$ & 80 & 40 & 40 & $50,5 \%$ & 293 & 144 & 149 & $50,8 \%$ \\
\hline Others Oceania & 228 & 108 & 120 & $52,6 \%$ & 79 & 36 & 43 & $54,2 \%$ & 86 & 43 & 43 & $50,3 \%$ \\
\hline Groups of interest & & & & & & & & & & & & \\
\hline OECD members & 28048 & 13832 & 14215 & $50,7 \%$ & 13187 & 6594 & 6593 & $50,0 \%$ & 8656 & 4356 & 4301 & $49,7 \%$ \\
\hline Large countries $(>75 \mathrm{M})$ & 18597 & 9138 & 9459 & $50,9 \%$ & 7974 & 3963 & 4011 & $50,3 \%$ & 7058 & 3510 & 3549 & $50,3 \%$ \\
\hline Sub-Saharan Africa & 2101 & 1108 & 993 & $47,3 \%$ & 672 & 330 & 342 & $50,9 \%$ & 916 & 528 & 388 & $42,4 \%$ \\
\hline LAC countries (e) & 13960 & 6971 & 6989 & $50,1 \%$ & 7317 & 3791 & 3526 & $48,2 \%$ & 3682 & 1755 & 1926 & $52,3 \%$ \\
\hline MENA countries ( $\mathrm{f}$ ) & 3823 & 2213 & 1610 & $42,1 \%$ & 1938 & 1082 & 856 & $44,2 \%$ & 1228 & 760 & 469 & $38,2 \%$ \\
\hline Islamic countries $(\mathrm{g})$ & 8624 & 4813 & 3811 & $44,2 \%$ & 4695 & 2527 & 2168 & $46,2 \%$ & 2380 & 1428 & 952 & $40,0 \%$ \\
\hline
\end{tabular}

(a) In the World total, we include individuals with unknown origin country.

(b) http://web.worldbank.org/WBSITE/EXTERNAL/DATASTATISTICS/0,,contentMDK:20420458 menuPK:64133156 pagePK:64133150 piPK:64133175 theSitePK:239419,00.html

(b) http://www.un.org/special-rep/ohrlls/ldc/list.htm; http://www.un.org/special-rep/ohrlls/llde/list.htm; http://www.un.org/special-rep/ohrlls/sid/list.htm

(d) http://unstats.un.org/unsd/methods/m49/m49regin.htm

(e) $\mathrm{LAC}=$ Cental Anerica + South America + The Caribbean; Sub-Saharan Africa = Africa - Northern Africa

(f) http://web.worldbank.org/WBSITE/EXTERNAL/COUNTRIES/MENAEXT/0,,menuPK:247606 pagePK:146732 piPK:146828 theSitePK:256299,00.html

(g) http://www.islamic-world.net/countries/index.htm 
Table 3. Top-30 total and skilled emigration stocks in 2000

\begin{tabular}{|c|c|c|c|c|c|c|c|c|c|}
\hline \multicolumn{6}{|c|}{ Total migration } & \multicolumn{3}{|c|}{ Skilled } & \multirow[b]{2}{*}{ Fem\% } \\
\hline Country & Both & Men & Women & Fem\% & Country & Both & Men & Women & \\
\hline Mexico & 6434391 & 3518573 & 2915818 & $45,3 \%$ & United Kingdom & 1478477 & 771923 & 706553 & $47,8 \%$ \\
\hline United Kingdom & 2990352 & 1443664 & 1546688 & $51,7 \%$ & Philippines & 1111075 & 441227 & 669848 & $60,3 \%$ \\
\hline Italy & 2336966 & 1242585 & 1094381 & $46,8 \%$ & India & 1034373 & 590412 & 443960 & $42,9 \%$ \\
\hline Germany & 2299491 & 978663 & 1320828 & $57,4 \%$ & Mexico & 949334 & 501324 & 448010 & $47,2 \%$ \\
\hline Turkey & 1942452 & 1055113 & 887339 & $45,7 \%$ & Germany & 936523 & 446085 & 490438 & $52,4 \%$ \\
\hline India & 1695646 & 896624 & 799022 & $47,1 \%$ & China & 783369 & 391455 & 391914 & $50,0 \%$ \\
\hline Philippines & 1677762 & 634329 & 1043434 & $62,2 \%$ & Korea & 612939 & 294123 & 318816 & $52,0 \%$ \\
\hline China & 1675535 & 787353 & 888182 & $53,0 \%$ & Canada & 523463 & 244693 & 278770 & $53,3 \%$ \\
\hline Vietnam & 1261395 & 622004 & 639391 & $50,7 \%$ & Vietnam & 505503 & 279239 & 226264 & $44,8 \%$ \\
\hline Portugal & 1209175 & 619630 & 589545 & $48,8 \%$ & Poland & 454560 & 206348 & 248213 & $54,6 \%$ \\
\hline Korea & 1205118 & 523637 & 681480 & $56,5 \%$ & United States & 426103 & 202872 & 223231 & $52,4 \%$ \\
\hline Poland & 1122078 & 492106 & 629972 & $56,1 \%$ & Italy & 395233 & 232840 & 162393 & $41,1 \%$ \\
\hline Morocco & 1067016 & 616834 & 450182 & $42,2 \%$ & Cuba & 331908 & 162359 & 169549 & $51,1 \%$ \\
\hline Cuba & 871708 & 417785 & 453923 & $52,1 \%$ & France & 310754 & 145310 & 165444 & $53,2 \%$ \\
\hline Canada & 853941 & 374095 & 479846 & $56,2 \%$ & Iran & 303385 & 181744 & 121642 & $40,1 \%$ \\
\hline France & 796016 & 357298 & 438717 & $55,1 \%$ & China, Hong Kong SAR & 292575 & 146980 & 145595 & $49,8 \%$ \\
\hline Ukraine & 747673 & 308590 & 439083 & $58,7 \%$ & Jamaica & 286932 & 108865 & 178068 & $62,1 \%$ \\
\hline Greece & 713826 & 381491 & 332335 & $46,6 \%$ & Japan & 278272 & 115096 & 163176 & $58,6 \%$ \\
\hline Spain & 710653 & 336202 & 374451 & $52,7 \%$ & Taiwan & 274168 & 124078 & 150089 & $54,7 \%$ \\
\hline Serbia and Montenegro & 683512 & 358190 & 325322 & $47,6 \%$ & Russia & 270445 & 114504 & 155940 & $57,7 \%$ \\
\hline Jamaica & 681075 & 293053 & 388022 & $57,0 \%$ & Netherlands & 254734 & 142438 & 112296 & $44,1 \%$ \\
\hline Ireland & 680459 & 312741 & 367719 & $54,0 \%$ & Ukraine & 249015 & 112195 & 136821 & $54,9 \%$ \\
\hline United States & 679598 & 322456 & 357141 & $52,6 \%$ & Colombia & 233073 & 105745 & 127328 & $54,6 \%$ \\
\hline El Salvador & 664942 & 328652 & 336290 & $50,6 \%$ & Ireland & 228144 & 111497 & 116646 & $51,1 \%$ \\
\hline Algeria & 609099 & 357386 & 251713 & $41,3 \%$ & Pakistan & 220591 & 138144 & 82447 & $37,4 \%$ \\
\hline Pakistan & 581903 & 329264 & 252638 & $43,4 \%$ & New Zealand & 174872 & 88391 & 86481 & $49,5 \%$ \\
\hline Dominican Republic & 578987 & 245058 & 333930 & $57,7 \%$ & Turkey & 174689 & 110977 & 63712 & $36,5 \%$ \\
\hline Colombia & 574924 & 240415 & 334509 & $58,2 \%$ & South Africa & 173021 & 87561 & 85461 & $49,4 \%$ \\
\hline Netherlands & 570984 & 293226 & 277758 & $48,6 \%$ & Peru & 163931 & 78561 & 85371 & $52,1 \%$ \\
\hline Russia & 552731 & 224711 & 328019 & $59,3 \%$ & Romania & 162904 & 82107 & 80797 & $49,6 \%$ \\
\hline
\end{tabular}




\section{Emigration rates}

We count as migrants all adult (25 and over) foreign-born individuals living in an OECD country. However, it is obvious that the pressure exerted by 1,036,000 Indian skilled emigrants ( $4.3 \%$ of the educated total adult population) is less important than the pressure exerted by 15,696 skilled emigrants from Grenada (84\% of the educated adult population). A more meaningful measure can then be obtained by comparing the emigration stocks to the total number of people born in the source country and belonging to the same gender and educational category. This method allows us to evaluate the pressure imposed on the labor market in the source country.

\subsection{Methodology and data sources}

In the spirit of Carrington and Detragiache (1998), Adams (2003), Docquier and Marfouk (2006) or Dumont and Lemaitre (2006), our second step consists in calculating the brain drain as a proportion of the total educated population born in the source country. Although our analysis is based on stocks (rather than flows), we will refer to these proportions as emigration rates. Denoting $N_{t, g, s}^{j}$ as the stock of individuals aged $25+$, of skill $s$, gender $g$, living in source country $i$, at time $t$, we define the emigration rates as

$$
m_{t, g, s}^{i}=\frac{M_{t, g, s}^{i}}{N_{t,, g s}^{i}+M_{t, g, s}^{i}}
$$

In particular, $m_{t, g, h}^{i}$ can be used as a proxy of the brain drain in the source country $i$.

This step requires using data on the size and the skill and gender structure of the adult population in the source countries. Population data by age are provided by the United Nations ${ }^{13}$. We focus on the population aged 25 and more. Data are missing for a couple of countries but can be estimated using the CIA world factbook ${ }^{14}$. Population data are split across educational group using international human capital indicators. Several sources based on attainment and/or enrollment variables can be found in the literature. As in Docquier and Marfouk (2006), human capital indicators are taken from De La Fuente and Domenech (2002) for OECD countries and from Barro and Lee (2001) for non-OECD countries. For countries where Barro and Lee measures are missing, we predict the proportion of educated using CohenSoto's measures (see Cohen and Soto, 2007). In the remaining countries where both Barro-Lee and Cohen-Soto data are missing (about 70 countries in 2000), we transpose the skill sharing of the neighboring country with the closest enrolment rate in secondary/tertiary education, the closest gender gap in enrolment rates and/or the closed GDP per capita. This method gives good approximations of the brain drain rate, broadly consistent with anecdotal evidence.

\footnotetext{
${ }^{13}$ See http://esa.un.org/unpp.

${ }^{14}$ See http://www.cia.gov/cia/publications/factbook.
} 
Tables 4.1 and 4.2 in appendix give the structure of the adult population $(25+)$ by country group and region of origin.

The world adult population increased from 2.559 to 3.180 billion people between 1990 and 2000 (+24.3 percent). This global growth rate hides important changes across education categories. While the unskilled population increased by 19.7 percent, the skilled populaiton rose by 52.5 percent. Consequently, the proportion of post-secondary educated workers in the world adult population increased from 9.1 to 11.1 percent over the period. Although women still face unequal access to education in many countries, is worth noticing that women's share in the skilled adult population increased from 40.4 to 44.5 percent (their share in the unskilled population remains above 55 percent). Our data reveal that gender gaps in human capital are strongly linked to the level of economic development. The share of women in the skilled population is still very low in low-income countries (30.3 percent) and in the least developed countries (28.5 percent). The educational achievement of women is particularly worrisome in Western Africa (13.3 percent) and Northern Africa (14.7 percent). Figure 3 compares the average annual growth rates of women's total/skilled and men's skilled adult population by region over the decade.

Figure 3. Annual average growth rate of total/skilled adult population $(25+)$

Data by region (1990-2000)

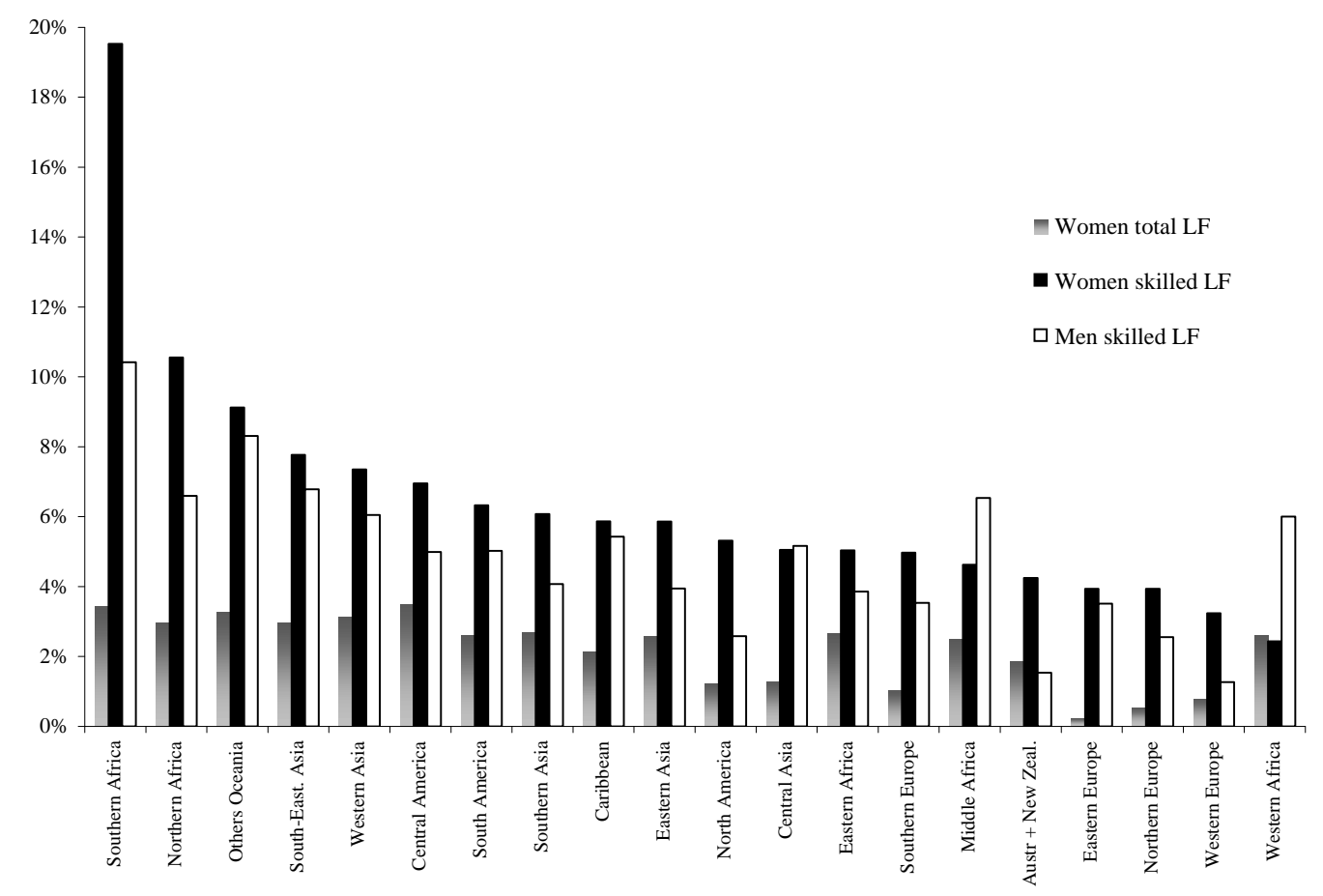


Table 4.1. Adult population (25+) by education and gender in 1990 (in thousands)

\begin{tabular}{|c|c|c|c|c|c|c|c|c|c|c|c|c|}
\hline & \multicolumn{4}{|c|}{ Total adult population (All education levels) } & \multicolumn{4}{|c|}{ Unskilled adult population (Less than secondary) } & \multicolumn{4}{|c|}{ Skilled adult population (post-secondary) } \\
\hline & Both & Men & Women & $\%$ & Both & Men & Women & $\%$ & Both & Men & Women & $\%$ \\
\hline $\begin{array}{l}\text { World } \\
\text { World Bank Income Classification (a) }\end{array}$ & 2558790 & 1265409 & 1293381 & $50,5 \%$ & 1575685 & 690634 & 885051 & $56,2 \%$ & 232292 & 138405 & 93887 & $40,4 \%$ \\
\hline High-income countries & 585129 & 281305 & 303824 & $51,9 \%$ & 198735 & 90484 & 108251 & $54,5 \%$ & 138946 & 78689 & 60256 & $43,4 \%$ \\
\hline Upper-Middle-income countries & 359928 & 170519 & 189409 & $52,6 \%$ & 198041 & 82375 & 115666 & $58,4 \%$ & 34850 & 19222 & 15628 & $44,8 \%$ \\
\hline Lower-Middle-income countries & 919340 & 463152 & 456187 & $49,6 \%$ & 599891 & 249743 & 350148 & $58,4 \%$ & 35787 & 23907 & 11880 & $33,2 \%$ \\
\hline $\begin{array}{l}\text { Low-income countries } \\
\text { nitions }\end{array}$ & 694394 & 350433 & 343961 & $49,5 \%$ & 579018 & 268032 & 310986 & $53,7 \%$ & 22710 & 16586 & 6123 & $27,0 \%$ \\
\hline $\begin{array}{l}\text { United Nations Classification (b) } \\
\text { Least Developed Countries }\end{array}$ & 189008 & 92640 & 96368 & $51,0 \%$ & 167550 & 76941 & 90609 & $54,1 \%$ & 3203 & 2403 & 800 & $25,0 \%$ \\
\hline Landlocked Developing countries & 108517 & 52310 & 56207 & $51,8 \%$ & 80333 & 35299 & 45034 & $56,1 \%$ & 5055 & 3047 & 2008 & $\begin{array}{l}25,0 \% \\
39,7 \%\end{array}$ \\
\hline $\begin{array}{l}\text { Small Island Developing countries } \\
\text { United Nations Classification (c) }\end{array}$ & 24960 & 12517 & 12444 & $49,9 \%$ & 19253 & 9373 & 9880 & $51,3 \%$ & 1213 & 732 & 481 & $39,7 \%$ \\
\hline Africa & 228448 & 111422 & 117026 & $51,2 \%$ & 197578 & 91085 & 106492 & $53,9 \%$ & 5720 & 4314 & 1406 & $24,6 \%$ \\
\hline Eastern Africa & 67073 & 32384 & 34689 & $51,7 \%$ & 60242 & 27730 & 32512 & $54,0 \%$ & 1031 & 721 & 310 & $30,1 \%$ \\
\hline Middle Africa & 25338 & 12141 & 13197 & $52,1 \%$ & 22195 & 9940 & 12255 & $55,2 \%$ & 351 & 291 & 60 & $17,2 \%$ \\
\hline Northern Africa & 56322 & 27827 & 28495 & $50,6 \%$ & 46804 & 21427 & 25376 & $54,2 \%$ & 2557 & 1905 & 651 & $25,5 \%$ \\
\hline Southern Africa & 16960 & 8184 & 8777 & $51,7 \%$ & 12448 & 5968 & 6480 & $52,1 \%$ & 620 & 442 & 178 & $28,7 \%$ \\
\hline Western Africa & 62756 & 30886 & 31870 & $50,8 \%$ & 55889 & 26020 & 29869 & $53,4 \%$ & 1162 & 955 & 207 & $17,8 \%$ \\
\hline Americas & 372244 & 179763 & 192480 & $51,7 \%$ & 163146 & 80129 & 83018 & $50,9 \%$ & 88679 & 48877 & 39802 & $44,9 \%$ \\
\hline Caribbean & 13321 & 6539 & 6782 & $50,9 \%$ & 9362 & 4470 & 4892 & $52,3 \%$ & 883 & 487 & 396 & $44,8 \%$ \\
\hline Central America & 43350 & 20862 & 22487 & $51,9 \%$ & 30665 & 14276 & 16390 & $53,4 \%$ & 3806 & 2348 & 1458 & $38,3 \%$ \\
\hline South America & 135012 & 65713 & 69298 & $51,3 \%$ & 101872 & 49100 & 52771 & $51,8 \%$ & 12382 & 6647 & 5735 & $46,3 \%$ \\
\hline North America & 180561 & 86649 & 93913 & $52,0 \%$ & 21247 & 12283 & 8964 & $42,2 \%$ & 71607 & 39395 & 32213 & $45,0 \%$ \\
\hline Asia & 1473723 & 748424 & 725300 & $49,2 \%$ & 1021116 & 447196 & 573920 & $56,2 \%$ & 69339 & 47075 & 22264 & $32,1 \%$ \\
\hline Central Asia & 22159 & 10485 & 11674 & $52,7 \%$ & 6273 & 1387 & 4886 & $77,9 \%$ & 2650 & 1492 & 1158 & $43,7 \%$ \\
\hline Eastern Asia & 701412 & 356889 & 344523 & $49,1 \%$ & 413492 & 165775 & 247717 & $59,9 \%$ & 33388 & 23046 & 10342 & $31,0 \%$ \\
\hline Southern Asia & 499396 & 256417 & 242979 & $48,7 \%$ & 408891 & 190467 & 218424 & $53,4 \%$ & 18313 & 13730 & 4583 & $25,0 \%$ \\
\hline South-Eastern Asia & 187498 & 92150 & 95348 & $50,9 \%$ & 147308 & 68337 & 78971 & $53,6 \%$ & 9820 & 5510 & 4310 & $43,9 \%$ \\
\hline Western Asia & 63258 & 32483 & 30775 & $48,7 \%$ & 45152 & 21230 & 23922 & $53,0 \%$ & 5168 & 3296 & 1871 & $36,2 \%$ \\
\hline Europe & 469662 & 218494 & 251168 & $53,5 \%$ & 188040 & 69492 & 118548 & $63,0 \%$ & 64797 & 35838 & 28959 & $44,7 \%$ \\
\hline Eastern Europe & 196640 & 89051 & 107589 & $54,7 \%$ & 56758 & 12251 & 44507 & $78,4 \%$ & 23405 & 12524 & 10881 & $46,5 \%$ \\
\hline Northern Europe & 60675 & 28691 & 31984 & $52,7 \%$ & 25100 & 11334 & 13766 & $54,8 \%$ & 9265 & 5034 & 4231 & $45,7 \%$ \\
\hline Southern Europe & 92936 & 44267 & 48669 & $52,4 \%$ & 68214 & 30850 & 37364 & $54,8 \%$ & 7449 & 4067 & 3382 & $45,4 \%$ \\
\hline Western Europe & 119411 & 56485 & 62926 & $52,7 \%$ & 37969 & 15058 & 22911 & $60,3 \%$ & 24678 & 14213 & 10465 & $42,4 \%$ \\
\hline Oceania & 14713 & 7306 & 7407 & $50,3 \%$ & 5805 & 2731 & 3073 & $52,9 \%$ & 3757 & 2301 & 1456 & $38,7 \%$ \\
\hline Australia and New Zealand & 12489 & 6122 & 6366 & $51,0 \%$ & 3881 & 1732 & 2150 & $55,4 \%$ & 3722 & 2277 & 1445 & $38,8 \%$ \\
\hline Others Oceania & 2224 & 1184 & 1041 & $46,8 \%$ & 1923 & 999 & 924 & $48,0 \%$ & 35 & 24 & 11 & $30,6 \%$ \\
\hline Groups of interest & & & & & & & & & & & & \\
\hline OECD members & 647623 & 309840 & 337783 & $52,2 \%$ & 241987 & 108823 & 133163 & $55,0 \%$ & 142651 & 80926 & 61726 & $43,3 \%$ \\
\hline Large countries $(>75 \mathrm{M})$ & 1697740 & 848562 & 849178 & $50,0 \%$ & 1031939 & 448934 & 583005 & $56,5 \%$ & 150862 & 91585 & 59277 & $39,3 \%$ \\
\hline Sub-Saharan Africa & 172127 & 83595 & 88532 & $51,4 \%$ & 150774 & 69658 & 81116 & $53,8 \%$ & 3164 & 2408 & 755 & $23,9 \%$ \\
\hline LAC countries & 191682 & 93115 & 98568 & $51,4 \%$ & 141899 & 67846 & 74054 & $52,2 \%$ & 17072 & 9483 & 7589 & $44,5 \%$ \\
\hline MENA countries (e) & 97083 & 49678 & 47405 & $48,8 \%$ & 75184 & 35317 & 39866 & $53,0 \%$ & 5878 & 4044 & 1834 & $31,2 \%$ \\
\hline Islamic countries (f) & 393474 & 196851 & 196623 & $50,0 \%$ & 314663 & 144283 & 170380 & $54,1 \%$ & 14885 & 10478 & 4407 & $29,6 \%$ \\
\hline
\end{tabular}

\begin{tabular}{l|c|c}
75184 \\
$50,0 \%$ & 314663 \\
\hline
\end{tabular}

144283

170380

年

(b) http://www.un.org/special-rep/ohrlls/ldc/list.htm; http://www.un.org/special-rep/ohrlls/llde/list.htm; http://www.un.org/special-rep/ohrlls/sid/list.htm

(c) http://unstats.un.org/unsd/methods/m49/m49regin.htm

(d) LAC $=$ Central America + South America + The Caribbean; Sub-Saharan Africa $=$ Africa - Northern Africa

(e) http://web.worldbank.org/WBSITE/EXTERNAL/COUNTRIES/MENAEXT/0,,menuPK:247606 pagePK:146732 piPK:146828 theSitePK:256299,00.html

(f) http://www.islamic-world.net/countries/index.htm 
Table 4.2. Adult population (25+) by education and gender in 2000 (in thousands)

\begin{tabular}{|c|c|c|c|c|c|c|c|c|c|c|c|c|}
\hline & \multicolumn{4}{|c|}{ Total adult population (All education levels) } & \multicolumn{4}{|c|}{ Unskilled adult population (Less than secondary) } & \multicolumn{4}{|c|}{ Skilled adult population (post-secondary) } \\
\hline & Both & Men & Women & $\%$ & Both & Men & Women & $\%$ & Both & Men & Women & $\%$ \\
\hline $\begin{array}{l}\text { World } \\
\text { World Bank Income Classification (a) }\end{array}$ & 3179718 & 1571014 & 1608705 & $50,6 \%$ & 1885976 & 835349 & 1050627 & $55,7 \%$ & 354282 & 196657 & 157625 & $44,5 \%$ \\
\hline High-income countries & 662506 & 320073 & 342433 & $51,7 \%$ & 187105 & 85076 & 102030 & $54,5 \%$ & 197637 & 101680 & 95958 & $48,6 \%$ \\
\hline Upper-Middle-income countries & 426226 & 201629 & 224597 & $52,7 \%$ & 229680 & 97447 & 132233 & $57,6 \%$ & 56532 & 30122 & 26410 & $46,7 \%$ \\
\hline Lower-Middle-income countries & 1187136 & 594021 & 593115 & $50,0 \%$ & 743374 & 317291 & 426083 & $57,3 \%$ & 64353 & 39946 & 24407 & $37,9 \%$ \\
\hline Low-income countries & 903851 & 455291 & 448560 & $49,6 \%$ & 725817 & 335535 & 390282 & $53,8 \%$ & 35760 & 24910 & 10851 & $30,3 \%$ \\
\hline \multicolumn{13}{|l|}{ United Nations Classification (b) } \\
\hline Least Developed Countries & 249873 & 122450 & 127423 & $51,0 \%$ & 215479 & 99367 & 116112 & $53,9 \%$ & 5777 & 4131 & 1646 & $28,5 \%$ \\
\hline Landlocked Developing countries & 136479 & 65749 & 70729 & $51,8 \%$ & 102761 & 45971 & 56790 & $55,3 \%$ & 8220 & 4858 & 3363 & $40,9 \%$ \\
\hline Small Island Developing countries & 33181 & 16588 & 16593 & $50,0 \%$ & 23333 & 11364 & 11970 & $51,3 \%$ & 2206 & 1273 & 933 & $42,3 \%$ \\
\hline \multicolumn{13}{|l|}{ United Nations Classification (c) } \\
\hline Africa & 300244 & 146437 & 153808 & $51,2 \%$ & 237175 & 108413 & 128762 & $54,3 \%$ & 11813 & 8112 & 3701 & $31,3 \%$ \\
\hline Eastern Africa & 87250 & 42114 & 45136 & $51,7 \%$ & 75730 & 35271 & 40458 & $53,4 \%$ & 1560 & 1053 & 507 & $32,5 \%$ \\
\hline Middle Africa & 32615 & 15739 & 16876 & $51,7 \%$ & 26346 & 11481 & 14865 & $56,4 \%$ & 642 & 547 & 95 & $14,7 \%$ \\
\hline Northern Africa & 75418 & 37220 & 38197 & $50,6 \%$ & 55457 & 25233 & 30225 & $54,5 \%$ & 5386 & 3610 & 1777 & $33,0 \%$ \\
\hline Southern Africa & 23453 & 11149 & 12304 & $52,5 \%$ & 10507 & 4456 & 6052 & $57,6 \%$ & 2250 & 1190 & 1060 & $47,1 \%$ \\
\hline Western Africa & 81509 & 40214 & 41295 & $50,7 \%$ & 69134 & 31971 & 37163 & $53,8 \%$ & 1975 & 1712 & 263 & $13,3 \%$ \\
\hline Americas & 455273 & 219276 & 235997 & $51,8 \%$ & 181841 & 86948 & 94894 & $52,2 \%$ & 134569 & 66349 & 68220 & $50,7 \%$ \\
\hline Caribbean & 16450 & 8066 & 8384 & $51,0 \%$ & 9945 & 4800 & 5145 & $51,7 \%$ & 1527 & 827 & 700 & $45,8 \%$ \\
\hline Central America & 60580 & 28895 & 31685 & $52,3 \%$ & 38669 & 17961 & 20708 & $53,6 \%$ & 6679 & 3822 & 2857 & $42,8 \%$ \\
\hline South America & 173793 & 83980 & 89814 & $51,7 \%$ & 120930 & 57977 & 62953 & $52,1 \%$ & 21447 & 10853 & 10595 & $49,4 \%$ \\
\hline North America & 204449 & 98335 & 106114 & $51,9 \%$ & 12298 & 6209 & 6088 & $49,5 \%$ & 104916 & 50847 & 54069 & $51,5 \%$ \\
\hline Asia & 1907394 & 963284 & 944110 & $49,5 \%$ & 1263557 & 560154 & 703403 & $55,7 \%$ & 114803 & 73439 & 41363 & $36,0 \%$ \\
\hline Central Asia & 25338 & 12062 & 13276 & $52,4 \%$ & 9106 & 2735 & 6371 & $70,0 \%$ & 4366 & 2469 & 1897 & $43,4 \%$ \\
\hline Eastern Asia & 896953 & 452397 & 444556 & $49,6 \%$ & 508642 & 211117 & 297525 & $58,5 \%$ & 52231 & 33946 & 18286 & $35,0 \%$ \\
\hline Southern Asia & 648079 & 331300 & 316779 & $48,9 \%$ & 507936 & 235540 & 272396 & $53,6 \%$ & 28739 & 20470 & 8269 & $28,8 \%$ \\
\hline South-Eastern Asia & 250518 & 122921 & 127598 & $50,9 \%$ & 180363 & 83883 & 96479 & $53,5 \%$ & 19729 & 10622 & 9107 & $46,2 \%$ \\
\hline Western Asia & 86506 & 44605 & 41900 & $48,4 \%$ & 57510 & 26879 & 30631 & $53,3 \%$ & 9737 & 5932 & 3805 & $39,1 \%$ \\
\hline Europe & 499035 & 233352 & 265684 & $53,2 \%$ & 197247 & 76869 & 120378 & $61,0 \%$ & 88175 & 46051 & 42124 & $47,8 \%$ \\
\hline Eastern Europe & 200828 & 90832 & 109996 & $54,8 \%$ & 67634 & 19006 & 48628 & $71,9 \%$ & 33705 & 17693 & 16012 & $47,5 \%$ \\
\hline Northern Europe & 64279 & 30592 & 33687 & $52,4 \%$ & 20508 & 9467 & 11041 & $53,8 \%$ & 12704 & 6479 & 6225 & $49,0 \%$ \\
\hline Southern Europe & 103439 & 49491 & 53947 & $52,2 \%$ & 67532 & 30653 & 36878 & $54,6 \%$ & 11250 & 5757 & 5493 & $48,8 \%$ \\
\hline Western Europe & 130490 & 62436 & 68054 & $52,2 \%$ & 41574 & 17743 & 23831 & $57,3 \%$ & 30515 & 16122 & 14394 & $47,2 \%$ \\
\hline Oceania & 17773 & 8665 & 9107 & $51,2 \%$ & 6156 & 2965 & 3191 & $51,8 \%$ & 4923 & 2706 & 2217 & $45,0 \%$ \\
\hline Australia and New Zealand & 14842 & 7170 & 7672 & $51,7 \%$ & 3683 & 1738 & 1945 & $52,8 \%$ & 4844 & 2653 & 2191 & $45,2 \%$ \\
\hline Others Oceania & 2931 & 1496 & 1435 & $49,0 \%$ & 2473 & 1227 & 1246 & $50,4 \%$ & 79 & 53 & 25 & $32,2 \%$ \\
\hline \multicolumn{13}{|l|}{ Groups of interest } \\
\hline OECD members & 739278 & 355109 & 384169 & $52,0 \%$ & 238790 & 107414 & 131376 & $55,0 \%$ & 203547 & 105145 & 98401 & $48,3 \%$ \\
\hline Large countries $(>75 \mathrm{M})$ & 2130619 & 1062349 & 1068270 & $50,1 \%$ & 1258734 & 553740 & 704994 & $56,0 \%$ & 224760 & 125793 & 98967 & $44,0 \%$ \\
\hline Sub-Saharan Africa & 224826 & 109216 & 115610 & $51,4 \%$ & 181718 & 83180 & 98538 & $54,2 \%$ & 6427 & 4502 & 1925 & $29,9 \%$ \\
\hline LAC countries & 250823 & 120941 & 129882 & $51,8 \%$ & 169543 & 80738 & 88805 & $52,4 \%$ & 29653 & 15502 & 14151 & $47,7 \%$ \\
\hline MENA countries (e) & 133690 & 68193 & 65497 & $49,0 \%$ & 90775 & 42064 & 48711 & $53,7 \%$ & 12205 & 7794 & 4411 & $36,1 \%$ \\
\hline Islamic countries (f) & 519936 & 260151 & 259785 & $50,0 \%$ & 393241 & 180297 & 212944 & $54,2 \%$ & 30324 & 20330 & 9994 & $33,0 \%$ \\
\hline
\end{tabular}$$
519936
$$

\begin{tabular}{l|r}
$49,0 \%$ & 90775 \\
$50,0 \%$ & 393241 \\
\hline
\end{tabular}

42064
180297

(a) http:/web. worlbank org/WBSITE/EXTERNAL/DATASTATISTICS/0,contentMDK·20420458 menuPK:64133156 pagePK:64133150 piPK:64133175 theSitePK:239419,00.htmI

(b) http://www.un.org/special-rep/ohrlls/ldc/list.htm; http://www.un.org/special-rep/ohrlls/lldc/list.htm; http://www.un.org/special-rep/ohrlls/sid/list.htm

(c) http://unstats.un.org/unsd/methods/m49/m49regin.htm

(d) $\mathrm{LAC}=$ Central America + South America + The Caribbean; Sub-Saharan Africa $=$ Africa - Northern Africa

(e) http://web.worldbank.org/WBSITE/EXTERNAL/COUNTRIES/MENAEXT/0,,menuPK:247606 pagePK:146732 piPK:146828 theSitePK:256299,00.html

(f) http://www.islamic-world.net/countries/index.htm 
It comes out that the highest growth rates were observed in the poorest regions of sub-Saharan Africa, Pacific islands and Southern Asia. The level of schooling of the adult population also increased significantly in Northern Africa. The change in the intensity of the brain drain will then result from the comparison of the growth rate of skilled emigrants with skilled residents/natives. In many African countries (except in Southern and Northern Africa) and in Central America and Southern Asia, the growth rate of the stock of skilled female emigrants exceeded the growth rate of the skilled female population. The brain drain increases significantly in these regions. The opposite movement was observed in Southern and Northern Africa, or in Pacific islands.

\subsection{Emigration rates by education level and gender}

Tables 5.1 and 5.2 show the emigration rates of unskilled and skilled workers, as well as global emigration rates by country groups and region of origin in 1990 and 2000 . The reported index gives the female/male ratio in emigration rates by education level. Our cross-country results are very similar to those described in Docquier and Marfouk (2006). The correlation between the old and updated skilled emigration rates in 2000 is 94 percent. Skilled emigration rates are high in small and poor countries. Small

developing islands of the Caribbean (47.2 percent) and the Pacific (63.1 percent) are particularly affected.

At the world level, women and men exhibit almost the same total emigration rates (1.6 percent in 1990 and 1.8 in 2000). Women's emigration rates are, however, lower than men's in the less developed countries, especially in Northern and sub-Saharan Africa. On the contrary, skilled emigration rates are more pronounced among women. In 2000, the average (weighted) female/male ratio of brain drain amounted to 1.20. Huge ratios were observed in regions where women have a poor access to education such as Middle Africa (2.225), Eastern Asia (2.030), Southern Africa (1.914) and Western Africa (1.842).

Between 1990 and 2000, and despite the rise in women's level of schooling, men's and women's skilled emigration rates slightly increased. Although the gender ratio of skilled migration rates decreased at the world level and in most regions, it rose in some developing regions such as Middle and Western Africa. 
Table 5.1. Rates of emigration by education and gender in 1990

\begin{tabular}{|c|c|c|c|c|c|c|c|c|c|c|c|c|}
\hline & \multicolumn{4}{|c|}{ Total migration (All education levels) } & \multicolumn{4}{|c|}{ Unskilled migration (Less than secondary) } & \multicolumn{4}{|c|}{ Skilled migration (post-secondary) } \\
\hline & Both & Males & Females & Ratio & Both & Males & Females & Ratio & Both & Males & Females & Ratio \\
\hline $\begin{array}{l}\text { World } \\
\text { World Bank Income Classification (a) }\end{array}$ & $1,6 \%$ & $1,6 \%$ & $1,6 \%$ & 1,001 & $1,2 \%$ & $1,4 \%$ & $1,1 \%$ & 0,833 & $5,0 \%$ & $4,5 \%$ & $5,7 \%$ & 1,273 \\
\hline High-income countries & $3,0 \%$ & $2,9 \%$ & $3,0 \%$ & 1,040 & $3,9 \%$ & $3,9 \%$ & $3,8 \%$ & 0,980 & $4,0 \%$ & $3,6 \%$ & $4,4 \%$ & 1,227 \\
\hline Upper-Middle-income countries & $2,5 \%$ & $2,7 \%$ & $2,3 \%$ & 0,845 & $2,7 \%$ & $3,2 \%$ & $2,3 \%$ & 0,694 & $5,5 \%$ & $5,5 \%$ & $5,5 \%$ & 1,008 \\
\hline Lower-Middle-income countries & $1,1 \%$ & $1,0 \%$ & $1,1 \%$ & 1,025 & $0,8 \%$ & $0,9 \%$ & $0,7 \%$ & 0,735 & $8,1 \%$ & $6,4 \%$ & $11,2 \%$ & 1,752 \\
\hline $\begin{array}{l}\text { Low-income countries } \\
\text { (nnifos }\end{array}$ & $0,5 \%$ & $0,5 \%$ & $0,5 \%$ & 0,848 & $0,3 \%$ & $0,3 \%$ & $0,3 \%$ & 0,886 & $5,5 \%$ & $4,7 \%$ & $7,5 \%$ & 1,582 \\
\hline $\begin{array}{l}\text { United Nations Classification (b) } \\
\text { Least Developed Countries }\end{array}$ & $0,7 \%$ & $0,8 \%$ & $0,6 \%$ & 0,781 & $0,4 \%$ & $0,5 \%$ & $0,4 \%$ & 0,815 & $11,4 \%$ & $9,7 \%$ & $16.1 \%$ & 1.657 \\
\hline Landlocked Developing countries & $0,7 \%$ & $0,8 \%$ & $0,6 \%$ & 0,803 & $0,5 \%$ & $0,5 \%$ & $0,4 \%$ & 0,746 & $5,0 \%$ & $4,8 \%$ & $5,3 \%$ & 1,104 \\
\hline $\begin{array}{l}\text { Small Island Developing countries } \\
\text { United Nations Classification (c) }\end{array}$ & $9,6 \%$ & $9,0 \%$ & $10,2 \%$ & 1,137 & $5,6 \%$ & $5,3 \%$ & $5,9 \%$ & 1,105 & $43,1 \%$ & $38,0 \%$ & $49,4 \%$ & 1,302 \\
\hline Africa & $1,2 \%$ & $1,5 \%$ & $1,0 \%$ & 0,663 & $0,9 \%$ & $1,1 \%$ & $0,7 \%$ & 0,624 & $11,2 \%$ & $9,7 \%$ & $15,6 \%$ & 1,608 \\
\hline Eastern Africa & $0,8 \%$ & $0,8 \%$ & $0,7 \%$ & 0,864 & $0,4 \%$ & $0,3 \%$ & $0,4 \%$ & 1,011 & $16,5 \%$ & $14,6 \%$ & $20,7 \%$ & 1,415 \\
\hline Middle Africa & $0,4 \%$ & $0,5 \%$ & $0,3 \%$ & 0,657 & $0,2 \%$ & $0,2 \%$ & $0,2 \%$ & 0,742 & $9,7 \%$ & $7,9 \%$ & $17,6 \%$ & 2,225 \\
\hline Northern Africa & $2,9 \%$ & $3,5 \%$ & $2,2 \%$ & 0,630 & $2,6 \%$ & $3,3 \%$ & $1,9 \%$ & 0,568 & $9,2 \%$ & $8,3 \%$ & $11,7 \%$ & 1,411 \\
\hline Southern Africa & $0,8 \%$ & $0,8 \%$ & $0,8 \%$ & 0,984 & $0,2 \%$ & $0,2 \%$ & $0,3 \%$ & 1,291 & $11,3 \%$ & $8,8 \%$ & $16,9 \%$ & 1,914 \\
\hline Western Africa & $0,7 \%$ & $0,8 \%$ & $0,5 \%$ & 0,565 & $0,4 \%$ & $0,5 \%$ & $0,3 \%$ & 0,567 & $11,0 \%$ & $9,5 \%$ & $17,4 \%$ & 1,842 \\
\hline Americas & $2,2 \%$ & $2,2 \%$ & $2,2 \%$ & 0,998 & $2,5 \%$ & $2,5 \%$ & $2,5 \%$ & 0,991 & $2,9 \%$ & $2,6 \%$ & $3,3 \%$ & 1,255 \\
\hline Caribbean & $12,8 \%$ & $12,2 \%$ & $13,4 \%$ & 1,103 & $8,2 \%$ & $8,0 \%$ & $8,4 \%$ & 1,053 & $44,0 \%$ & $40,4 \%$ & $47,8 \%$ & 1,182 \\
\hline Central America & $7,4 \%$ & $8,0 \%$ & $6,9 \%$ & 0,854 & $7,3 \%$ & $8,2 \%$ & $6,5 \%$ & 0,794 & $13,7 \%$ & $12,0 \%$ & $16,2 \%$ & 1,350 \\
\hline South America & $1,2 \%$ & $1,1 \%$ & $1,2 \%$ & 1,114 & $0,5 \%$ & $0,4 \%$ & $0,5 \%$ & 1,236 & $4,8 \%$ & $4,5 \%$ & $5,2 \%$ & 1,144 \\
\hline North America & $0,8 \%$ & $0,7 \%$ & $0,8 \%$ & 1,176 & $1,9 \%$ & $1,4 \%$ & $2,5 \%$ & 1,797 & $1,0 \%$ & $0,8 \%$ & $1,2 \%$ & 1,389 \\
\hline Asia & $0,6 \%$ & $0,6 \%$ & $0,6 \%$ & 1,016 & $0,4 \%$ & $0,4 \%$ & $0,4 \%$ & 0,849 & $5,2 \%$ & $4,2 \%$ & $7,1 \%$ & 1,699 \\
\hline Central Asia & $0,2 \%$ & $0,2 \%$ & $0,2 \%$ & 1,043 & $0,3 \%$ & $0,6 \%$ & $0,2 \%$ & 0,306 & $0,3 \%$ & $0,3 \%$ & $0,4 \%$ & 1,522 \\
\hline Eastern Asia & $0,4 \%$ & $0,3 \%$ & $0,4 \%$ & 1,209 & $0,2 \%$ & $0,2 \%$ & $0,2 \%$ & 0,945 & $3,7 \%$ & $2,8 \%$ & $5,7 \%$ & 2,030 \\
\hline Southern Asia & $0,4 \%$ & $0,4 \%$ & $0,4 \%$ & 0,824 & $0,2 \%$ & $0,2 \%$ & $0,2 \%$ & 0,853 & $4,4 \%$ & $3,8 \%$ & $6,4 \%$ & 1,684 \\
\hline South-Eastern Asia & $1,4 \%$ & $1,3 \%$ & $1,5 \%$ & 1,156 & $0,6 \%$ & $0,6 \%$ & $0,7 \%$ & 1,176 & $10,8 \%$ & $9,4 \%$ & $12,5 \%$ & 1,324 \\
\hline Western Asia & $3,3 \%$ & $3,6 \%$ & $3,0 \%$ & 0,828 & $3,1 \%$ & $3,6 \%$ & $2,7 \%$ & 0,773 & $8,0 \%$ & $8,0 \%$ & $7,9 \%$ & 0,987 \\
\hline Europe & $4,0 \%$ & $4,1 \%$ & $3,8 \%$ & 0,943 & $4,9 \%$ & $6,2 \%$ & $4,2 \%$ & 0,684 & $7,0 \%$ & $6,7 \%$ & $7,3 \%$ & 1,090 \\
\hline Eastern Europe & $1,8 \%$ & $1,9 \%$ & $1,8 \%$ & 0,935 & $3,2 \%$ & $6,3 \%$ & $2,3 \%$ & 0,368 & $3,6 \%$ & $3,6 \%$ & $3,5 \%$ & 0,979 \\
\hline Northern Europe & $6,9 \%$ & $6,7 \%$ & $7,1 \%$ & 1,053 & $5,7 \%$ & $5,5 \%$ & $5,8 \%$ & 1,053 & $14,4 \%$ & $13,7 \%$ & $15,4 \%$ & 1,124 \\
\hline Southern Europe & $7,0 \%$ & $7,6 \%$ & $6,3 \%$ & 0,827 & $6,5 \%$ & $7,3 \%$ & $5,9 \%$ & 0,807 & $11,5 \%$ & $12,3 \%$ & $10,4 \%$ & 0,845 \\
\hline Western Europe & $3,4 \%$ & $3,2 \%$ & $3,7 \%$ & 1,158 & $4,1 \%$ & $4,1 \%$ & $4,1 \%$ & 0,986 & $5,6 \%$ & $5,0 \%$ & $6,5 \%$ & 1,310 \\
\hline Oceania & $3,4 \%$ & $3,3 \%$ & $3,5 \%$ & 1,066 & $2,2 \%$ & $2,1 \%$ & $2,2 \%$ & 1,066 & $5,5 \%$ & $4,7 \%$ & $6,9 \%$ & 1,457 \\
\hline Australia and New Zealand & $3,0 \%$ & $2,9 \%$ & $3,0 \%$ & 1,042 & $1,9 \%$ & $1,9 \%$ & $1,9 \%$ & 0,990 & $4,3 \%$ & $3,6 \%$ & $5,3 \%$ & 1,480 \\
\hline Others Oceania & $6,0 \%$ & $5,4 \%$ & $6,6 \%$ & 1,213 & $2,7 \%$ & $2,5 \%$ & $3,1 \%$ & 1,252 & $61,2 \%$ & $54,3 \%$ & $71,0 \%$ & 1,306 \\
\hline Groups of interest & & & & & & & & & & & & \\
\hline OECD members & $3,4 \%$ & $3,4 \%$ & $3,3 \%$ & 0,978 & $4,5 \%$ & $4,8 \%$ & $4,3 \%$ & 0,887 & $4,1 \%$ & $3,8 \%$ & $4,5 \%$ & 1,199 \\
\hline Large countries $(>75 \mathrm{M})$ & $0,6 \%$ & $0,6 \%$ & $0,6 \%$ & 1,061 & $0,5 \%$ & $0,5 \%$ & $0,4 \%$ & 0,843 & $2,4 \%$ & $2,1 \%$ & $3,0 \%$ & 1,418 \\
\hline Sub-Saharan Africa & $0,7 \%$ & $0,8 \%$ & $0,6 \%$ & 0,739 & $0,3 \%$ & $0,4 \%$ & $0,3 \%$ & 0,782 & $12,8 \%$ & $10,8 \%$ & $18,7 \%$ & 1,734 \\
\hline LAC countries & $3,5 \%$ & $3,6 \%$ & $3,5 \%$ & 0,975 & $2,6 \%$ & $2,7 \%$ & $2,5 \%$ & 0,917 & $10,1 \%$ & $9,3 \%$ & $11,2 \%$ & 1,211 \\
\hline MENA countries (e) & $2,8 \%$ & $3,2 \%$ & $2,3 \%$ & 0,704 & $2,1 \%$ & $2,6 \%$ & $1,7 \%$ & 0,645 & $11,3 \%$ & $10,9 \%$ & $12,1 \%$ & 1,112 \\
\hline Islamic countries (f) & $1,5 \%$ & $1,7 \%$ & $1,2 \%$ & 0,737 & $1,1 \%$ & $1,4 \%$ & $0,9 \%$ & 0,671 & $8,1 \%$ & $7,4 \%$ & $9,6 \%$ & 1,296 \\
\hline
\end{tabular}

(a) http://web.

(b) http://www.un.org/special-rep/ohrlls/ldc/list.htm; http://www.un.org/special-rep/ohrlls/lddc/list.htm; http://www.un.org/special-rep/ohrlls/sid/list.htm

(c) http://unstats.un.org/unsd/methods/m49/m49regin.htm

(d) $\mathrm{LAC}=$ Central America + South America + The Caribbean; Sub-Saharan Africa $=$ Africa - Northern Africa

(e) http://web.worldbank.org/WBSITE/EXTERNAL/COUNTRIES/MENAEXT/0,,menuPK:247606 pagePK:146732 piPK:146828 theSitePK:256299,00.html

(f) http://www.islamic-world.net/countries/index.htm 
Table 5.2. Rates of emigration by education and gender in 2000

\begin{tabular}{|c|c|c|c|c|c|c|c|c|c|c|c|c|}
\hline & \multicolumn{4}{|c|}{ Total migration (All education levels) } & \multicolumn{4}{|c|}{ Unskilled migration (Less than secondary) } & \multicolumn{4}{|c|}{ Skilled migration (post-secondary) } \\
\hline & Both & Males & Females & Ratio & Both & Males & Females & Ratio & Both & Males & Females & Ratio \\
\hline $\begin{array}{l}\text { World } \\
\text { World Bank Income Classification (a) }\end{array}$ & $1,8 \%$ & $1,8 \%$ & $1,8 \%$ & 1,011 & $1,3 \%$ & $1,4 \%$ & $1,2 \%$ & 0,833 & $5,4 \%$ & $5,0 \%$ & $6,0 \%$ & 1,200 \\
\hline High-income countries & $2,9 \%$ & $2,8 \%$ & $3,0 \%$ & 1,045 & $3,6 \%$ & $3,6 \%$ & $3,5 \%$ & 0,964 & $3,8 \%$ & $3,7 \%$ & $4,0 \%$ & 1,068 \\
\hline Upper-Middle-income countries & $3,5 \%$ & $3,8 \%$ & $3,2 \%$ & 0,859 & $3,6 \%$ & $4,4 \%$ & $3,0 \%$ & 0,694 & $6,2 \%$ & $5,9 \%$ & $6,5 \%$ & 1,103 \\
\hline Lower-Middle-income countries & $1,3 \%$ & $1,2 \%$ & $1,3 \%$ & 1,077 & $0,9 \%$ & $1,0 \%$ & $0,8 \%$ & 0,797 & $8,1 \%$ & $6,5 \%$ & $10,7 \%$ & 1,657 \\
\hline 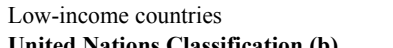 & $0,7 \%$ & $0,7 \%$ & $0,7 \%$ & 0,920 & $0,3 \%$ & $0,3 \%$ & $0,3 \%$ & 0,981 & $7,5 \%$ & $6,3 \%$ & $10,2 \%$ & 1,615 \\
\hline $\begin{array}{l}\text { United Nations Classification (b) } \\
\text { Least Developed Countries }\end{array}$ & $0,9 \%$ & $1.0 \%$ & $0.9 \%$ & 0.877 & $0.5 \%$ & $0.5 \%$ & $0.5 \%$ & 0.915 & $12,3 \%$ & $10,3 \%$ & $17.1 \%$ & 1666 \\
\hline Landlocked Developing countries & $1,0 \%$ & $1,0 \%$ & $0,9 \%$ & 0,891 & $0,5 \%$ & $0,5 \%$ & $0,5 \%$ & 0,862 & $6,0 \%$ & $5,5 \%$ & $6,7 \%$ & $\begin{array}{l}1,220 \\
1,220\end{array}$ \\
\hline $\begin{array}{l}\text { Small Island Developing countries } \\
\text { United Nations Classification (c) }\end{array}$ & $11,1 \%$ & $10,1 \%$ & $11,9 \%$ & 1,176 & $6,4 \%$ & $6,0 \%$ & $6,8 \%$ & 1,121 & $41,0 \%$ & $35,5 \%$ & $47,2 \%$ & 1,330 \\
\hline Africa & $1,4 \%$ & $1,6 \%$ & $1,2 \%$ & 0,753 & $0,9 \%$ & $1,1 \%$ & $0,7 \%$ & 0,699 & $10,4 \%$ & $9,2 \%$ & $13,1 \%$ & 1,427 \\
\hline Eastern Africa & $0,9 \%$ & $0,9 \%$ & $0,9 \%$ & 0,957 & $0,3 \%$ & $0,3 \%$ & $0,3 \%$ & 1,215 & $18,1 \%$ & $15,6 \%$ & $23,0 \%$ & 1,481 \\
\hline Middle Africa & $0,7 \%$ & $0,7 \%$ & $0,6 \%$ & 0,807 & $0,3 \%$ & $0,4 \%$ & $0,3 \%$ & 0,883 & $10,4 \%$ & $7,9 \%$ & $22,6 \%$ & 2,863 \\
\hline Northern Africa & $2,9 \%$ & $3,4 \%$ & $2,4 \%$ & 0,688 & $2,6 \%$ & $3,2 \%$ & $2,0 \%$ & 0,630 & $7,8 \%$ & $7,4 \%$ & $8,6 \%$ & 1,160 \\
\hline Southern Africa & $1,1 \%$ & $1,2 \%$ & $1,1 \%$ & 0,988 & $0,3 \%$ & $0,3 \%$ & $0,3 \%$ & 1,006 & $7,3 \%$ & $7,0 \%$ & $7,6 \%$ & 1,085 \\
\hline Western Africa & $1,0 \%$ & $1,1 \%$ & $0,8 \%$ & 0,721 & $0,5 \%$ & $0,6 \%$ & $0,4 \%$ & 0,682 & $13,9 \%$ & $10,3 \%$ & $31,7 \%$ & 3,065 \\
\hline Americas & $3,3 \%$ & $3,4 \%$ & $3,2 \%$ & 0,950 & $4,0 \%$ & $4,3 \%$ & $3,7 \%$ & 0,867 & $3,3 \%$ & $3,2 \%$ & $3,4 \%$ & 1,070 \\
\hline Caribbean & $15,5 \%$ & $14,3 \%$ & $16,6 \%$ & 1,157 & $10,4 \%$ & $9,9 \%$ & $10,8 \%$ & 1,093 & $43,0 \%$ & $38,0 \%$ & $47,9 \%$ & 1,261 \\
\hline Central America & $11,7 \%$ & $13,0 \%$ & $10,6 \%$ & 0,817 & $12,1 \%$ & $13,9 \%$ & $10,6 \%$ & 0,760 & $17,1 \%$ & $15,6 \%$ & $19,0 \%$ & 1,217 \\
\hline South America & $1,6 \%$ & $1,6 \%$ & $1,7 \%$ & 1,113 & $0,7 \%$ & $0,6 \%$ & $0,7 \%$ & 1,152 & $5,1 \%$ & $4,8 \%$ & $5,5 \%$ & 1,151 \\
\hline North America & $0,7 \%$ & $0,7 \%$ & $0,8 \%$ & 1,113 & $2,2 \%$ & $2,0 \%$ & $2,5 \%$ & 1,263 & $0,9 \%$ & $0,9 \%$ & $0,9 \%$ & 1,054 \\
\hline Asia & $0,8 \%$ & $0,8 \%$ & $0,8 \%$ & 1,073 & $0,4 \%$ & $0,4 \%$ & $0,4 \%$ & 0,918 & $5,7 \%$ & $4,7 \%$ & $7,6 \%$ & 1,631 \\
\hline Central Asia & $0,3 \%$ & $0,3 \%$ & $0,3 \%$ & 1,141 & $0,3 \%$ & $0,5 \%$ & $0,2 \%$ & 0,480 & $0,9 \%$ & $0,7 \%$ & $1,2 \%$ & 1,757 \\
\hline Eastern Asia & $0,5 \%$ & $0,4 \%$ & $0,5 \%$ & 1,255 & $0,2 \%$ & $0,2 \%$ & $0,2 \%$ & 0,997 & $4,1 \%$ & $3,1 \%$ & $6,0 \%$ & 1,962 \\
\hline Southern Asia & $0,5 \%$ & $0,6 \%$ & $0,5 \%$ & 0,869 & $0,2 \%$ & $0,2 \%$ & $0,2 \%$ & 0,912 & $6,0 \%$ & $5,0 \%$ & $8,3 \%$ & 1,676 \\
\hline South-Eastern Asia & $1,7 \%$ & $1,5 \%$ & $1,9 \%$ & 1,252 & $0,7 \%$ & $0,6 \%$ & $0,8 \%$ & 1,304 & $9,8 \%$ & $8,5 \%$ & $11,4 \%$ & 1,343 \\
\hline Western Asia & $3,5 \%$ & $3,7 \%$ & $3,3 \%$ & 0,881 & $3,3 \%$ & $3,7 \%$ & $3,0 \%$ & 0,806 & $7,1 \%$ & $7,0 \%$ & $7,1 \%$ & 1,013 \\
\hline Europe & $4,1 \%$ & $4,2 \%$ & $4,0 \%$ & 0,961 & $4,3 \%$ & $5,1 \%$ & $3,8 \%$ & 0,738 & $7,2 \%$ & $7,0 \%$ & $7,5 \%$ & 1,066 \\
\hline Eastern Europe & $2,2 \%$ & $2,1 \%$ & $2,2 \%$ & 1,014 & $2,4 \%$ & $3,6 \%$ & $2,0 \%$ & 0,544 & $4,5 \%$ & $4,0 \%$ & $4,9 \%$ & 1,215 \\
\hline Northern Europe & $6,7 \%$ & $6,6 \%$ & $6,8 \%$ & 1,032 & $5,2 \%$ & $5,0 \%$ & $5,4 \%$ & 1,098 & $14,0 \%$ & $13,8 \%$ & $14,1 \%$ & 1,022 \\
\hline Southern Europe & $6,8 \%$ & $7,3 \%$ & $6,2 \%$ & 0,853 & $6,5 \%$ & $7,2 \%$ & $5,9 \%$ & 0,820 & $10,9 \%$ & $11,8 \%$ & $10,0 \%$ & 0,848 \\
\hline Western Europe & $3,4 \%$ & $3,2 \%$ & $3,6 \%$ & 1,131 & $3,3 \%$ & $3,2 \%$ & $3,3 \%$ & 1,056 & $5,7 \%$ & $5,4 \%$ & $6,1 \%$ & 1,138 \\
\hline Oceania & $4,3 \%$ & $4,2 \%$ & $4,3 \%$ & 1,020 & $2,5 \%$ & $2,5 \%$ & $2,5 \%$ & 1,020 & $7,1 \%$ & $6,5 \%$ & $8,0 \%$ & 1,233 \\
\hline Australia and New Zealand & $3,7 \%$ & $3,7 \%$ & $3,6 \%$ & 0,990 & $2,1 \%$ & $2,2 \%$ & $2,0 \%$ & 0,914 & $5,7 \%$ & $5,2 \%$ & $6,4 \%$ & 1,233 \\
\hline Others Oceania & $7,2 \%$ & $6,7 \%$ & $7,7 \%$ & 1,144 & $3,1 \%$ & $2,9 \%$ & $3,3 \%$ & 1,158 & $52,3 \%$ & $44,6 \%$ & $63,1 \%$ & 1,416 \\
\hline Groups of interest & & & & & & & & & & & & \\
\hline OECD members & $3,7 \%$ & $3,7 \%$ & $3,6 \%$ & 0,952 & $5,2 \%$ & $5,8 \%$ & $4,8 \%$ & 0,826 & $4,1 \%$ & $4,0 \%$ & $4,2 \%$ & 1,053 \\
\hline Large countries $(>75 \mathrm{M})$ & $0,9 \%$ & $0,9 \%$ & $0,9 \%$ & 1,029 & $0,6 \%$ & $0,7 \%$ & $0,6 \%$ & 0,796 & $3,0 \%$ & $2,7 \%$ & $3,5 \%$ & 1,275 \\
\hline Sub-Saharan Africa & $0,9 \%$ & $1,0 \%$ & $0,9 \%$ & 0,848 & $0,4 \%$ & $0,4 \%$ & $0,3 \%$ & 0,876 & $12,5 \%$ & $10,5 \%$ & $16,8 \%$ & 1,601 \\
\hline LAC countries & $5,3 \%$ & $5,4 \%$ & $5,1 \%$ & 0,937 & $4,1 \%$ & $4,5 \%$ & $3,8 \%$ & 0,852 & $11,0 \%$ & $10,2 \%$ & $12,0 \%$ & 1,178 \\
\hline MENA countries (e) & $2,8 \%$ & $3,1 \%$ & $2,4 \%$ & 0,763 & $2,1 \%$ & $2,5 \%$ & $1,7 \%$ & 0,689 & $9,1 \%$ & $8,9 \%$ & $9,6 \%$ & 1,082 \\
\hline Islamic countries (f) & $1,6 \%$ & $1,8 \%$ & $1,4 \%$ & 0,796 & $1,2 \%$ & $1,4 \%$ & $1,0 \%$ & 0,729 & $7,3 \%$ & $6,6 \%$ & $8,7 \%$ & 1,325 \\
\hline
\end{tabular}

(a) http:/Wc.

(b) http://www.un.org/special-rep/ohrlls/ldc/list.htm; http://www.un.org/special-rep/ohrlls/lldc/list.htm; http://www.un.org/special-rep/ohrlls/sid/list.htm

(c) http://unstats.un.org/unsd/methods/m49/m49regin.htm

(d) $\mathrm{LAC}=$ Central America + South America + The Caribbean; Sub-Saharan Africa $=$ Africa - Northern Africa

(e) http://web.worldbank.org/WBSITE/EXTERNAL/COUNTRIES/MENAEXT/0,,menuPK:247606 pagePK:146732 piPK:146828 theSitePK:256299,00.html

(f) http://www.islamic-world.net/countries/index.htm 
Table 6 depicts the situation of the 30 most affected countries in 2000 regarding skilled migration rates. The right panel is based on the full sample. Small islands are the most affected. The emigration rate exceeds 80 percent in nations such as Guyana, Jamaica, St. Vincent, Grenada, Haiti, Cape Verde and Palau. Only three of these top-30 countries have a population above 4 million. On the right panel, we eliminate small countries and focus on countries with more than 4 million inhabitants. About one third of the most affected countries are located in sub-Saharan Africa and 7 are Central American or Caribbean countries. The brain drain exceed 30 percent in nine countries, including five sub-Saharan African ones.

Regarding gender disparities, Figure 4.1 and 4.2 compares stock and rates of skilled migration by gender. Figure 4.1 shows that the correlation in stocks is extremely high (97 percent). On average, the number of skilled female migrants is lower than the number of skilled men. Figure 4.2 reveals that the correlation is lower in rates (88 percent); women's rate is on average 17 percent above men's. However, the female/male ratio in emigration rates varies strongly across countries. As shown on Table 7, it ranges from 0.522 in Bhutan to 4.378 in Nigeria. Countries where women are disproportionately affected are Nigeria, Cameroon, Sao Tome and Principe, the Democratic Republic of Congo, Angola and Guinea. On the other hand, men are over-represented in Bhutan, Lesotho, Cambodia, Saudi Arabia, Jordan and Botswana. This gender gap in skilled emigration rate is strongly correlated with the gender gap in educational attainment of residents. It is especially strong in countries where women have little access to education. A simple regression of the log of the female/male ratio in skilled emigration rates on the log of the female/male ratio in post-secondary educated adult population gives an elasticity of -50 percent $\left(R^{2}=.54\right)$ and an intercept which is not significantly different from zero. Hence, equating men and women's educational attainment would strongly reduce the gender gap in skilled migration. It is also worth noticing that the correlation between the gender gap in skilled migration and variables such as the UN gender empowerment measure or the proportions of seats held by women in the parliament is almost equal to zero. 
Figure 4.1. Women's and men's brain drain in 2000 - Stocks

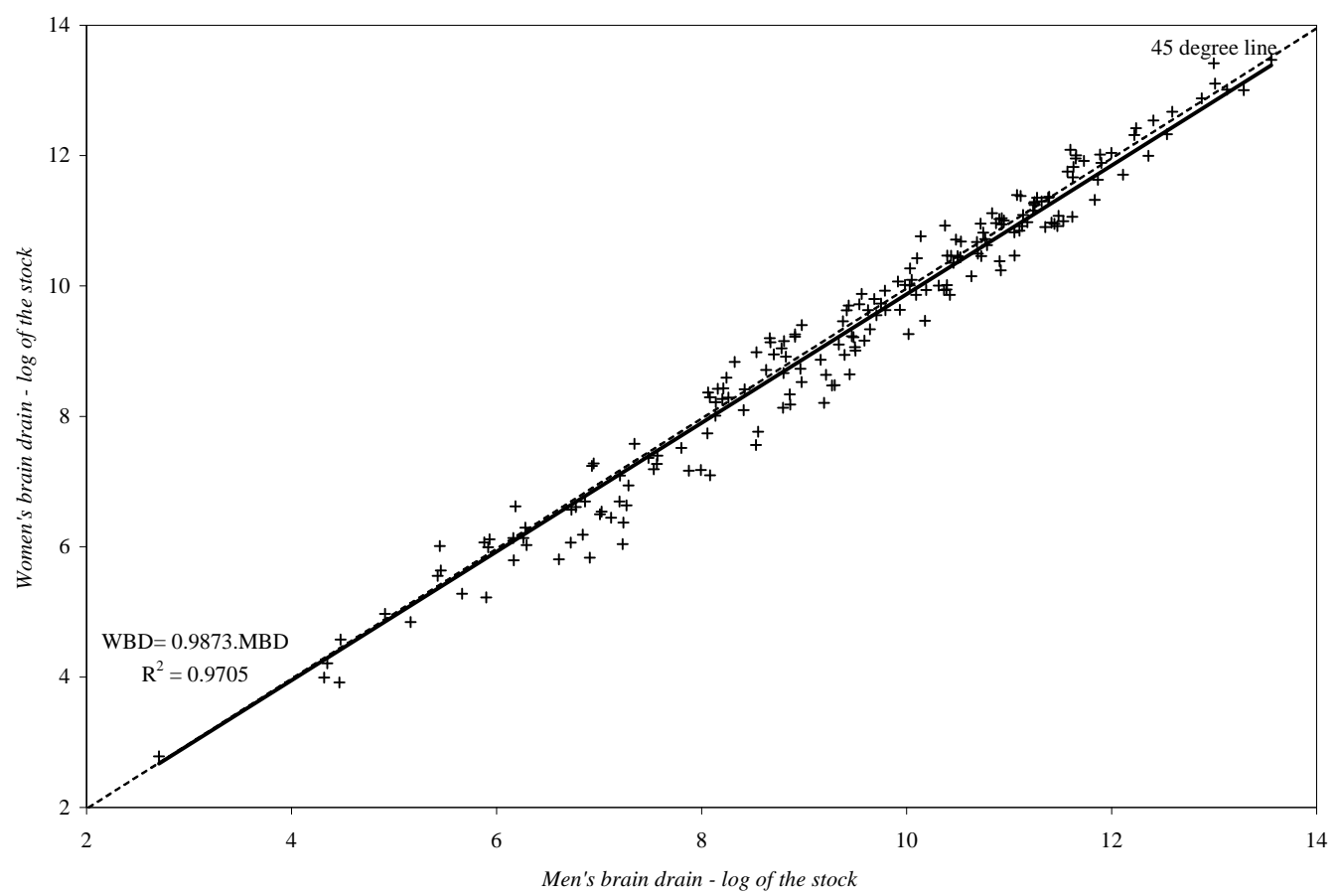

Figure 4.2. Women's and men's brain drain in 2000 - Rates

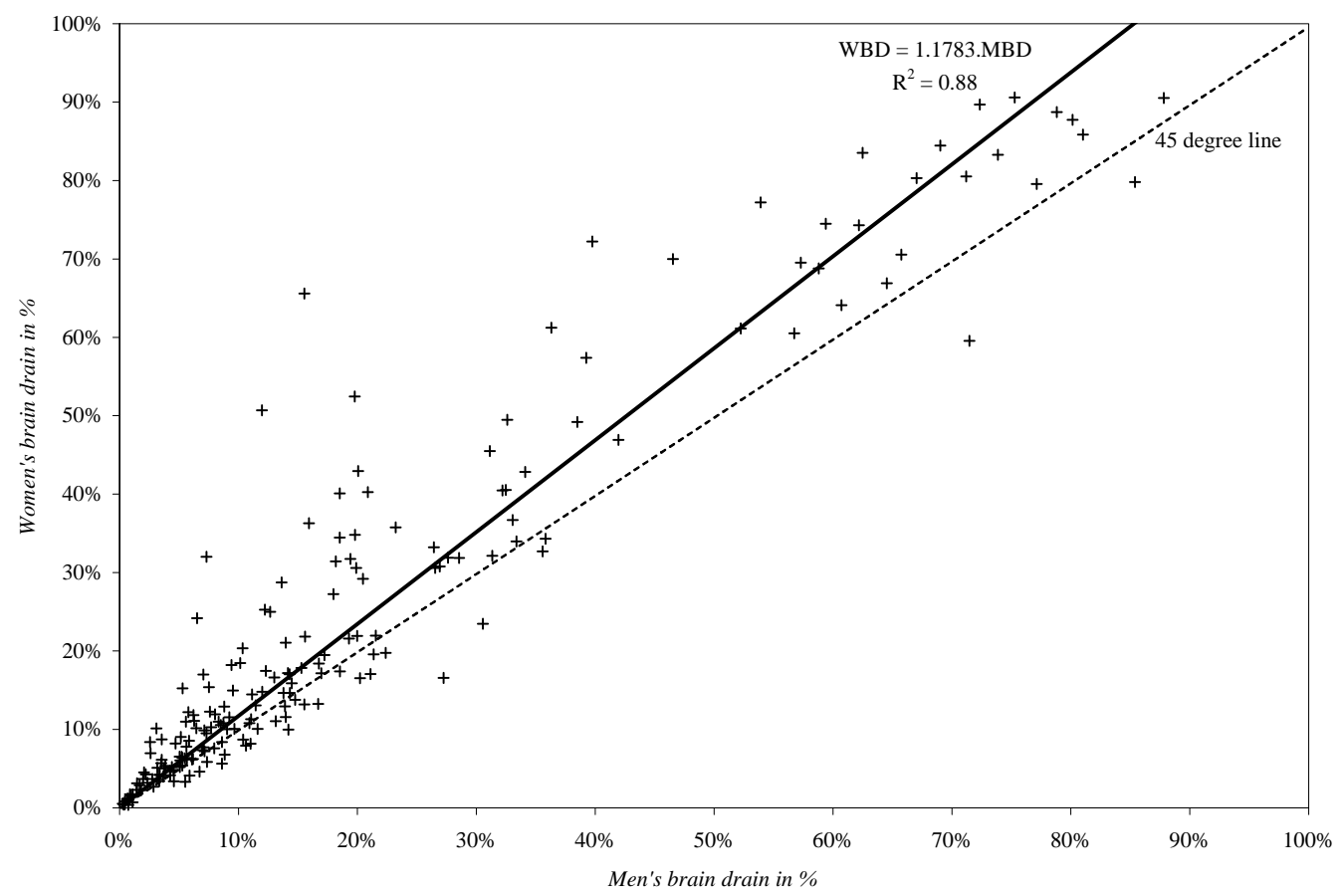


Table 6. Top-30 skilled emigration rates in 2000

\begin{tabular}{|c|c|c|c|c|c|c|c|c|c|}
\hline \multirow[b]{2}{*}{ Country } & \multicolumn{4}{|c|}{ "Skilled migration (all countries) } & \multicolumn{5}{|c|}{ Skilled migration (excluding small countries) } \\
\hline & Both & Men & Women & $\mathbf{F} / \mathbf{M}$ & Country & Both & Men & Women & $\mathbf{F} / \mathbf{M}$ \\
\hline Guyana & $89,2 \%$ & $87,8 \%$ & $90,5 \%$ & 1,031 & Haiti & $83,4 \%$ & $81,0 \%$ & $85,8 \%$ & 1,059 \\
\hline Jamaica & $84,7 \%$ & $80,2 \%$ & $87,7 \%$ & 1,095 & Sierra Leone & $49,2 \%$ & $39,8 \%$ & $72,2 \%$ & 1,817 \\
\hline Saint Vincent and the Grenadin & $84,6 \%$ & $78,8 \%$ & $88,7 \%$ & 1,126 & Ghana & $44,6 \%$ & $39,3 \%$ & $57,4 \%$ & 1,462 \\
\hline Grenada & $84,3 \%$ & $75,3 \%$ & $90,6 \%$ & 1,203 & Kenya & $38,5 \%$ & $32,6 \%$ & $49,5 \%$ & 1,518 \\
\hline Haiti & $83,4 \%$ & $81,0 \%$ & $85,8 \%$ & 1,059 & Laos & $37,2 \%$ & $34,1 \%$ & $42,8 \%$ & 1,255 \\
\hline Cape Verde & $82,4 \%$ & $85,4 \%$ & $79,8 \%$ & 0,934 & Uganda & $36,0 \%$ & $31,1 \%$ & $45,5 \%$ & 1,461 \\
\hline Palau & $80,9 \%$ & $72,4 \%$ & $89,7 \%$ & 1,239 & Somalia & $34,5 \%$ & $33,1 \%$ & $36,7 \%$ & 1,110 \\
\hline Trinidad and Tobago & $78,9 \%$ & $73,9 \%$ & $83,3 \%$ & 1,127 & El Salvador & $31,7 \%$ & $31,3 \%$ & $32,2 \%$ & 1,026 \\
\hline Saint Kitts and Nevis & $78,5 \%$ & $77,1 \%$ & $79,6 \%$ & 1,032 & Nicaragua & $30,2 \%$ & $28,6 \%$ & $31,9 \%$ & 1,116 \\
\hline Seychelles & $77,2 \%$ & $69,0 \%$ & $84,4 \%$ & 1,223 & China, Hong Kong SAR & $29,6 \%$ & $27,6 \%$ & $31,9 \%$ & 1,154 \\
\hline Tonga & $75,6 \%$ & $71,2 \%$ & $80,5 \%$ & 1,131 & Cuba & $28,8 \%$ & $26,9 \%$ & $30,8 \%$ & 1,144 \\
\hline Samoa & $73,4 \%$ & $67,0 \%$ & $80,3 \%$ & 1,198 & Sri Lanka & $28,2 \%$ & $26,5 \%$ & $30,6 \%$ & 1,153 \\
\hline Nauru & $72,0 \%$ & $62,5 \%$ & $83,5 \%$ & 1,337 & Papua New Guinea & $27,8 \%$ & $20,1 \%$ & $43,0 \%$ & 2,141 \\
\hline Saint Lucia & $68,6 \%$ & $62,2 \%$ & $74,3 \%$ & 1,195 & Vietnam & $26,9 \%$ & $30,5 \%$ & $23,5 \%$ & 0,769 \\
\hline Antigua and Barbuda & $68,5 \%$ & $65,7 \%$ & $70,6 \%$ & 1,073 & Rwanda & $26,3 \%$ & $20,9 \%$ & $40,3 \%$ & 1,929 \\
\hline Gambia, The & $67,8 \%$ & $71,5 \%$ & $59,5 \%$ & 0,833 & Honduras & $24,8 \%$ & $19,4 \%$ & $31,7 \%$ & 1,635 \\
\hline Suriname & $65,8 \%$ & $64,5 \%$ & $66,9 \%$ & 1,037 & Croatia & $24,6 \%$ & $20,5 \%$ & $29,2 \%$ & 1,427 \\
\hline Belize & $65,5 \%$ & $53,9 \%$ & $77,2 \%$ & 1,432 & Guatemala & $23,9 \%$ & $19,9 \%$ & $30,6 \%$ & 1,537 \\
\hline Tuvalu & $64,9 \%$ & $59,4 \%$ & $74,5 \%$ & 1,254 & Afghanistan & $22,6 \%$ & $18,5 \%$ & $34,5 \%$ & 1,863 \\
\hline Dominica & $63,9 \%$ & $58,8 \%$ & $68,8 \%$ & 1,170 & Mozambique & $22,5 \%$ & $18,2 \%$ & $31,4 \%$ & 1,727 \\
\hline Fiji & $62,8 \%$ & $57,3 \%$ & $69,5 \%$ & 1,213 & Dominican Republic & $22,4 \%$ & $18,0 \%$ & $27,2 \%$ & 1,515 \\
\hline Barbados & $62,6 \%$ & $60,7 \%$ & $64,1 \%$ & 1,056 & Cambodia & $21,4 \%$ & $27,3 \%$ & $16,6 \%$ & 0,608 \\
\hline Malta & $58,3 \%$ & $56,7 \%$ & $60,5 \%$ & 1,066 & Malawi & $20,9 \%$ & $15,9 \%$ & $36,3 \%$ & 2,281 \\
\hline Mauritius & $55,8 \%$ & $52,2 \%$ & $61,1 \%$ & 1,170 & Portugal & $18,9 \%$ & $21,1 \%$ & $17,1 \%$ & 0,809 \\
\hline Kiribati & $55,7 \%$ & $46,5 \%$ & $70,0 \%$ & 1,504 & Morocco & $18,0 \%$ & $17,2 \%$ & $19,5 \%$ & 1,130 \\
\hline Sierra Leone & $49,2 \%$ & $39,8 \%$ & $72,2 \%$ & 1,817 & Cameroon & $17,1 \%$ & $12,0 \%$ & $50,7 \%$ & 4,231 \\
\hline Ghana & $44,6 \%$ & $39,3 \%$ & $57,4 \%$ & 1,462 & Senegal & $17,1 \%$ & $15,6 \%$ & $21,8 \%$ & 1,401 \\
\hline Liberia & $44,3 \%$ & $36,3 \%$ & $61,2 \%$ & 1,686 & United Kingdom & $17,1 \%$ & $17,0 \%$ & $17,2 \%$ & 1,012 \\
\hline Lebanon & $43,8 \%$ & $42,0 \%$ & $46,9 \%$ & 1,118 & Zambia & $16,4 \%$ & $14,0 \%$ & $21,0 \%$ & 1,506 \\
\hline Marshall Islands & $42,8 \%$ & $38,5 \%$ & $49,2 \%$ & 1,279 & Togo & $16,3 \%$ & $13,6 \%$ & $28,7 \%$ & 2,110 \\
\hline
\end{tabular}


Table 7. Ratio of women to men in skilled migration (year 2000)

\begin{tabular}{|c|c|c|c|c|}
\hline & Country & Stock ratio & Country & Rate ratio \\
\hline \multirow{20}{*}{$\begin{array}{l}\text { Highest } \\
\text { ratio } \\
\text { Top-20 }\end{array}$} & Finland & 1,873 & Nigeria & 4,376 \\
\hline & Andorra & 1,758 & Cameroon & 4,231 \\
\hline & Thailand & 1,735 & Sao Tome and Principe & 4,224 \\
\hline & Grenada & 1,707 & Congo, Dem. Rep. of the & 3,711 \\
\hline & Bahamas, The & 1,667 & Guinea & 3,273 \\
\hline & Jamaica & 1,636 & Angola & 3,269 \\
\hline & Georgia & 1,589 & Burundi & 2,874 \\
\hline & Saint Vincent and the Grenadines & 1,562 & China & 2,682 \\
\hline & Turkmenistan & 1,544 & Guinea-Bissau & 2,651 \\
\hline & Estonia & 1,527 & Bangladesh & 2,462 \\
\hline & Philippines & 1,518 & Benin & 2,409 \\
\hline & Antigua and Barbuda & 1,423 & Malawi & 2,281 \\
\hline & Belize & 1,422 & Burkina Faso & 2,186 \\
\hline & Japan & 1,418 & Solomon Islands & 2,167 \\
\hline & Kazakhstan & 1,412 & Thailand & 2,152 \\
\hline & Seychelles & 1,392 & Papua New Guinea & 2,141 \\
\hline & Panama & 1,383 & Madagascar & 2,111 \\
\hline & Dominican Republic & 1,376 & Togo & 2,110 \\
\hline & Barbados & 1,376 & Mali & 2,069 \\
\hline & Tajikistan & 1,362 & Mauritania & 2,047 \\
\hline \multirow{20}{*}{$\begin{array}{l}\text { Lowest } \\
\text { ratio } \\
\text { Bottom-20 }\end{array}$} & Nepal & 0,515 & Bulgaria & 0,839 \\
\hline & Burkina Faso & 0,511 & Gambia, The & 0,833 \\
\hline & Djibouti & 0,508 & Hungary & 0,830 \\
\hline & Bangladesh & 0,507 & Liechtenstein & 0,817 \\
\hline & Saudi Arabia & 0,503 & Portugal & 0,809 \\
\hline & Mali & 0,493 & Sudan & 0,798 \\
\hline & Tunisia & 0,490 & San Marino & 0,793 \\
\hline & Jordan & 0,470 & Vietnam & 0,769 \\
\hline & Togo & 0,456 & Israel & 0,766 \\
\hline & Congo, Rep. of the & 0,451 & Uruguay & 0,745 \\
\hline & Sudan & 0,450 & Italy & 0,742 \\
\hline & Niger & 0,449 & Burma (Myanmar) & 0,739 \\
\hline & Benin & 0,443 & Greece & 0,703 \\
\hline & Senegal & 0,441 & Botswana & 0,699 \\
\hline & Central African Republic & 0,421 & Yemen & 0,685 \\
\hline & Yemen & 0,378 & Jordan & 0,653 \\
\hline & Gambia, The & 0,372 & Saudi Arabia & 0,639 \\
\hline & Cote d'Ivoire & 0,372 & Cambodia & 0,608 \\
\hline & Chad & 0,340 & Lesotho & 0,602 \\
\hline & Mauritania & 0,304 & Bhutan & 0,516 \\
\hline
\end{tabular}




\section{Conclusion}

In this paper, we build on the DM06 data set, update the data using new sources, homogenize 1990 and 2000 concepts, and introduce the gender breakdown. We provide revised stocks and rates of emigration by level of schooling and gender. We repeat the exercise for 1990 and 2000, thus shedding light on the recent feminization of the brain drain. We provide emigration stocks and rates for 195 countries in 1990 and 2000. Although our data set deserves some extensions (e.g. adding points in time and accounting for migration to non OECD destination countries), it can reasonably be used to capture the recent trend in women's brain drain, as well as to analyze its causes and consequences for developing countries.

Our gross data reveal that the share of women in the skilled immigrant population increased in almost all OECD destination countries between 1990 and 2000. Consequently, for the vast majority of source regions, the growth rates of skilled women emigrants were always bigger than the growth rates obtained for unskilled women or skilled men. This evolution particularly occurs in the least developed countries. This feminization of the South-North brain drain mostly reflects gendered changes in the supply of education. The cross-country correlation between emigration stocks of women and men is extremely high (about 97 percent), with women's numbers slightly below men's ones. However, these women skilled migrants are drawn from a much smaller population. Hence, in relative terms, the cross-country correlation in rates (88 percent) is much lower than in stocks. On average, women's brain drain is 17 percent above men's. This gender gap in skilled emigration rate is strongly correlated with the gender gap in the educational attainment of adult populations, reflecting unequal access to education in many source countries. Equating men and women's educational attainment at origin would almost strongly reduce the gender gap in skilled migration.

\section{References}

[1] Adams, R. (2003): International migration, remittances and the brain drain: a study of 24 labor-exporting countries, World Bank Policy Research Working Paper, n. 2972.

[2] Alders, M. (2001): Classification of the population with foreign background in the Netherlands, Statistics Netherlands, Paper for the conference "The measure and Mismeasure of Populations. The statistical use of ethnic and racial categories in multicultural societies", CERI-INED, Paris, 17-18 December.

[3] Barro, R.J. and J.W. Lee (2000): International data on educational attainment: updates and implications, Oxford Economic Papers 53, 541-563. 
[4] Beata J. S., C. Ozden, M. Spatareanu, C. Neagu (2006): Migrant networks and foreign direct investment, Policy, Research working paper ; no. WPS 4046, World Bank.

[5] Berhman, J.R., A.D. Foster, M.R. Rosenzweig and P. Vashishtha (1997): Women's schooling, home teaching, and economic growth, Manuscript.

[6] Beine, M., F. Docquier and H. Rapoport (2007a): Measuring international skilled migration: a new database controlling for age of entry, World Bank Economic Review, 21: 249 - 254.

[7] Beine, M., F. Docquier and H. Rapoport (2007b): Brain drain and growth in LDCs: winners and losers, Economic Journal, forthcoming.

[8] Blackden, M., S. Canagarajah, S. Klase and D. Lawson (2006): gender and growth in sub-Saharan Africa, UNU-WIDER Research Paper n. 2006-37.

[9] Bhorat, H., J-B. Meyer and C. Mlatsheni (2002): Skilled labor migration from developing countries: study on South and southern Africa, International migration papers, International Labor Office (ILO), Geneva.

[10] Carrington, W.J. and E. Detragiache (1998): How big is the brain drain?, IMF Working paper WP/98/102.

[11] Carrington, W.J. and E. Detragiache (1999): How extensive is the brain drain, Finance and Development, June: 46-49.

[12] Checchi, D., G. De Simone, R. Faini (2007): Skilled Migration, FDI and Human Capital Investment, IZA Discussion Paper, 2795.

[13] Clemens, M.A. and G. Pettersson (2006): A New database of health professional emigration from Africa, Working Paper, 95, Center for Global Development.

[14] Collinson, M., S. Tollman, K. Kahn and S. Clark (2003): Highly prevalent circular migration: households, mobility and economic status in rural South Africa, paper presented at the Conference on Migration in Comparative Perspective, Johannesburg, Sout Africa, 4-7 June.

[15] Commander, S., M. Kangasniemi and L.A. Winters (2004): The brain drain: a review of theory and facts, Brussels Economic Review, 47(1), Special issue on skilled migration, 29-44.

[16] Cohen, D. and M. Soto (2007): Growth and human capital: good data, good results, Journal of Economic Growth 12(1), 51-76.

[17] Coulombe, S. and J-F. Tremblay (2006): Literacy and growth, topics in macroeconomics $6(2)$, article 4 . 
[18] Debuisson, M., F. Docquier, A. Noury, M. Nantcho (2004): Immigration and aging in the Belgian regions, Brussels Economic Review, 47(1), Special issue on skilled migration, 138-158.

[19] Defoort, C. (2006): Tendances de long terme en migrations internationales: analyse à partir de 6 pays receveurs, Manuscript, Université Catholique de Louvain.

[20] De la Fuente, A. and R. Domenech (2002): Human capital in growth regressions: how much difference does data quality make? Un update and further results, CEPR Discussion Paper, n. 3587.

[21] Docquier, F. and A. Bhargava (2006): Medical brain drain - A New Panel Data Set on Physicians' Emigration Rates (1991-2004), Report, World Bank, Washington DC.

[22] Docquier, F., O. Lohest, and A. Marfouk (2007): Brain drain in developing countries, World Bank Economic Review 21: 193 - 218.

[23] Docquier, F. and A. Marfouk (2004): Measuring the international mobility of skilled workers - Release 1.0, Policy Research Working Paper n. 3382, World Bank (August 2004).

[24] Docquier, F. and H. Rapoport (2007): Skilled migration - The perspective of sending countries, In J. Baghwati and G. Hanson (eds), Skilled migration: prospects, problems and policies, Russell Sage Foundatation: New York, forthcoming.

[25] Dollar, D. and R. Gatti (1999): Gender inequality, income and growth - Are good times good for women?, Policy Research Report on Gender and Development, Working paper series, n.1, World Bank.

[26] Dumont, J.C. and Lemaître G. (2004): Counting immigrants and expatriates in OECD countries: a new perspective, Mimeo: OECD.

[27] Dumont, J.C., J.P. Martin and G. Spielvogel (2007): Women on the move: the neglected gender dimension of the brain drain, IZA Discussion Paper, n. 2920.

[28] Easterly, W and Y. Nyarko (2005): Is the brain drain good for Africa?, Mimeo: New York University.

[29] Grogger, J. and G.H. Hanson (2007): Income maximization and the sorting of emigrants across destinations, Mimeo, University of Chicago.

[30] Haveman, R. and B. Wolfe (1995): The determinants of children's attainments A review of methods and findings, Journal of Economic Literature 33(4), 18291878. 
[31] Hatton, T.J. and J.G. Williamson (2002): What fundamentals drive world migration?, NBER Working paper, n. 9159.

[32] Klasen, S. (1999): Does gender ineauqlity reduce growth and development? Evidence from cross-country regressions, Policy Research Report on Gender and Development, Working paper series, n.7, World Bank.

[33] Knowles, S., P.K. Lorgelly and P.D. Owen (2000): Are educational gender gaps a brake on economic development? Some cross-country empirical evidence. Manuscript.

[34] Kugler, M. and H. Rapoport (2007). International labour and capital flows: Substitutes or complements? Economics Letters, 92 (2), 155-162.

[35] Andrew R. Morrison, A.R., M. Schiff and M. Sjöblom (2007), The international migration of women, Palgrave McMillan.

[36] Nimi, Y. and C. Ozden (2006): Migrationm remittances and the brain drain: causes and linkages, mimeo (World Bank).

[37] OECD (2002): Trends in international migration, Paris: OECD Editions.

[38] Ruggles, S., M. Sobek, T. Alexander, C.A. Fitch, R. Goeken, P.K. Hall, M. King and C. Ronnander (2004): Integrated Public Use Microdata Series: Version 3.0. Minneapolis, MN: Minnesota Population Center.

[39] Sobek, M., S. Ruggles, R. McCaa, M. King, and D. Levison (2002): Integrated Public Use Microdata Series-International: Preliminary Version 1.0. Minneapolis: Minnesota Population Center, University of Minnesota.

[40] Summers, L.H. (1992): Investing in all the people, Pakistan Development Review $31(4), 367-406$.

[41] United Nations (2002): International Migration Report 2002, New York: United Nations. 
Département des Sciences Économiques de l'Université catholique de Louvain

Institut de Recherches Économiques et Sociales

Place Montesquieu, 3

1348 Louvain-la-Neuve, Belgique 